\title{
Characterization of the Contents and Histology of the Gastrointestinal Tracts of White Sturgeon (Acipenser transmontanus) Captured from Upper Lake Roosevelt, Washington, October 2008
}

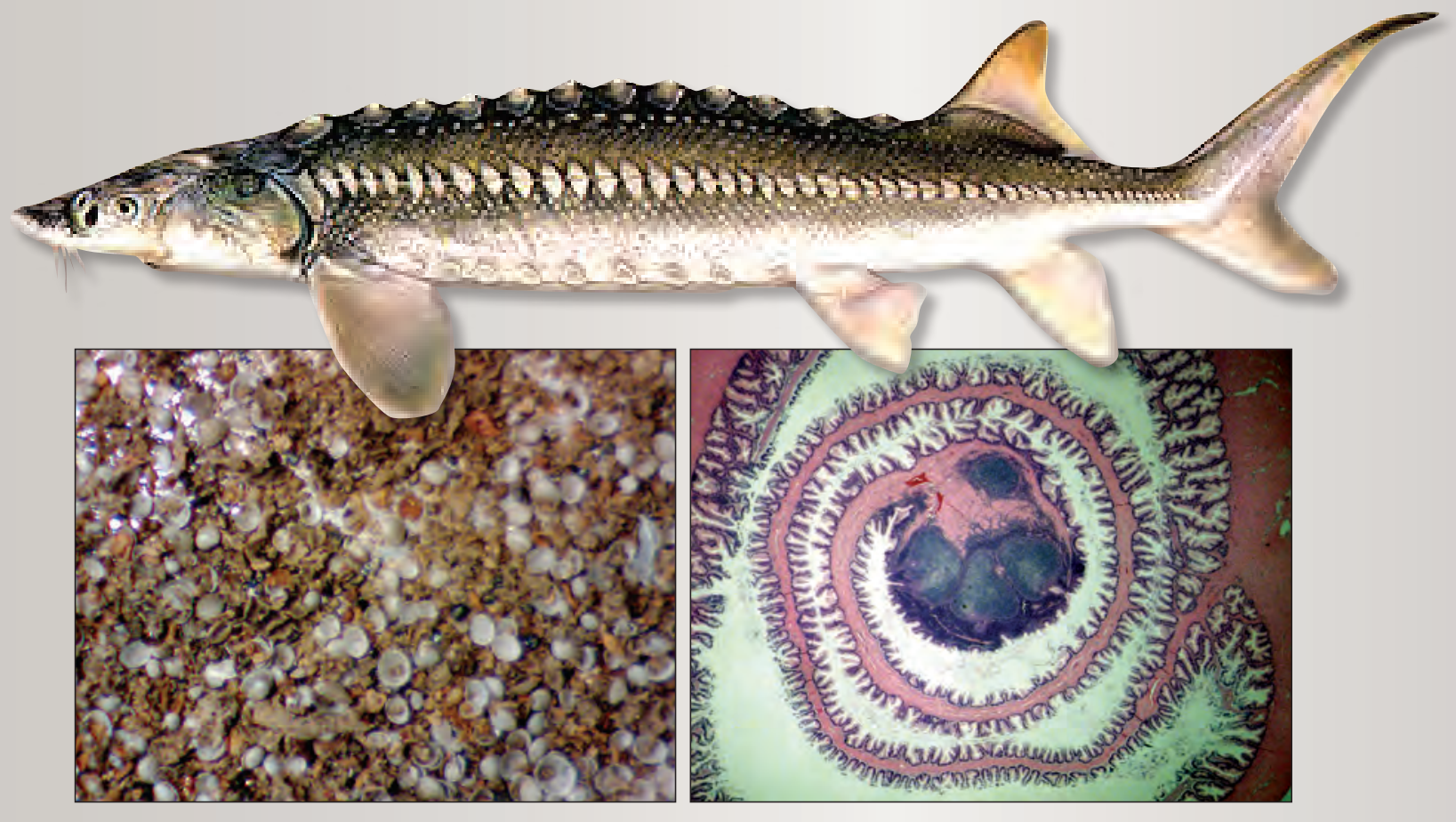

Open-File Report 2010-1193 
Cover: Photographs of white sturgeon, ashed contents from a gut, and a stained cross section of tissues from a control fish. The drawing of the white sturgeon was done by Nonindigenous Aquatic Species (NAS), an information resource for the U.S. Geological Survey. The histology cross section was provided by Carla Conway, U.S. Geological Survey. The ashed contents image was provided by Michael Parsley, U.S. Geological Survey. 


\section{Characterization of the Contents and Histology of the Gastrointestinal Tracts of White Sturgeon (Acipenser transmontanus) Captured from Upper Lake Roosevelt, Washington, October 2008}

By Michael J. Parsley, Bjorn K. van der Leeuw, and Diane G. Elliott

Open-File Report 2010-1193

U.S. Department of the Interior

U.S. Geological Survey 


\section{U.S. Department of the Interior \\ KEN SALAZAR, Secretary}

\section{U.S. Geological Survey \\ Marcia K. McNutt, Director}

U.S. Geological Survey, Reston, Virginia: 2010

For more information on the USGS-the Federal source for science about the Earth, its natural and living resources, natural hazards, and the environment, visit http://www.usgs.gov or call 1-888-ASK-USGS.

For an overview of USGS information products, including maps, imagery, and publications, visit $h$ ttp://www.usgs.gov/pubprod

To order this and other USGS information products, visit http://store.usgs.gov

Suggested citation:

Parsley, M.J., van der Leeuw, B.K., and Elliott, D.G., 2010, Characterization of the contents and histology of the gastrointestinal tracts of White Sturgeon (Acipenser transmontanus) captured from Upper Lake Roosevelt, Washington, October 2008: U.S. Geological Survey Open-File Report 2010-1193, 24 p.

Any use of trade, product, or firm names is for descriptive purposes only and does not imply endorsement by the U.S. Government.

Although this report is in the public domain, permission must be secured from the individual copyright owners to reproduce any copyrighted material contained within this report. 


\section{Contents}

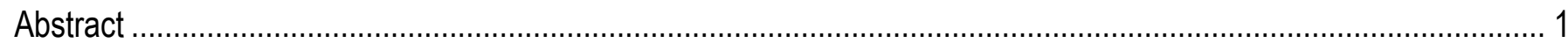

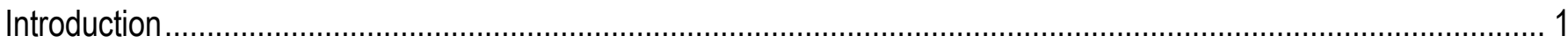

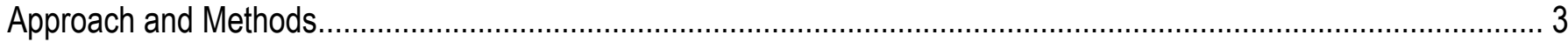

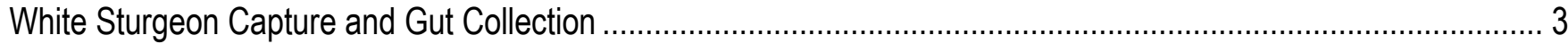

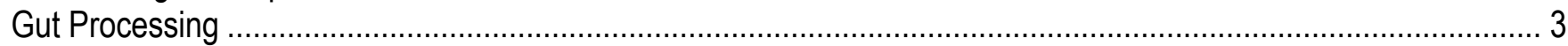

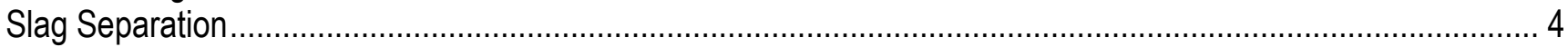

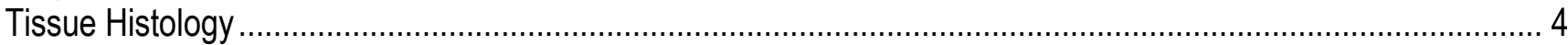

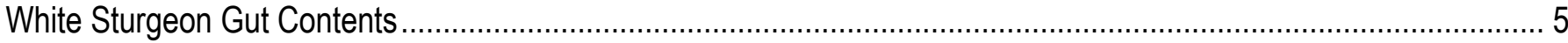

Slag

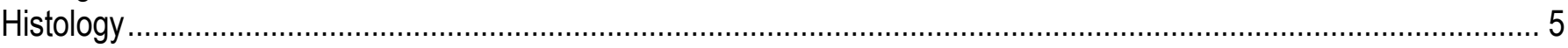

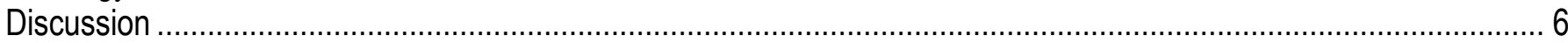

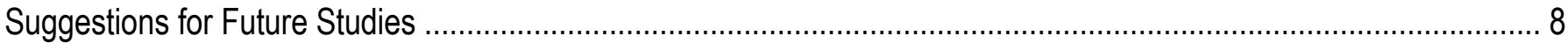

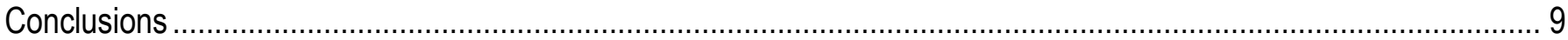

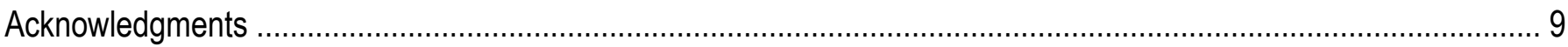

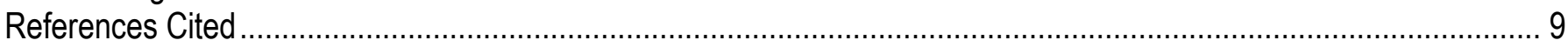

\section{Figures}

Figure 1. Map showing Columbia River Basin and the Lake Roosevelt study area

Figure 2. Photographs of a selection of slag particles (upper image) and particles observed in a Lake Roosevelt white sturgeon gut (lower image)

Figure 3. Map showing locations in upper Lake Roosevelt where 37 white sturgeon were captured for gut analysis. 14

Figure 4. Plot of lengths and weights of 37 white sturgeon captured from Lake Roosevelt in October 2008 ............. 15

Figure 5. Graph showing categories of items observed in the gut contents of white sturgeon captured from Lake Roosevelt in October 2008

Figure 6. Graph showing ranked plot of the number of different categories of food items found in 37 individual white sturgeon guts from Lake Roosevelt captured in October 2008 ..................................................................... 16

Figure 7. Graph showing dry weight of the total gut contents from individual white sturgeon from Lake Roosevelt ... 16

Figure 8. Graph showing weight of gut contents lost during combustion ......................................................... 17

Figure 9. Graph showing non-digestable portion of the total gut contents expressed as a percentage of the total

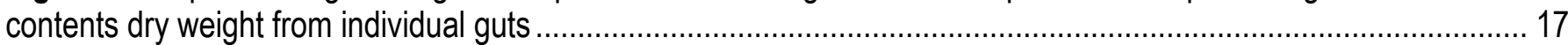

Figure 10. Graph showing weight of slag present in each gut of white sturgeon captured from Lake Roosevelt....... 18

Figure 11. Graph showing the spatial distribution of the percent, by weight, of slag found in the guts of

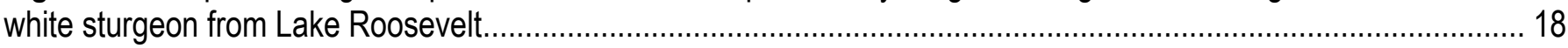

Figure 12. Photographs of histological sections of proximal (straight) intestine of juvenile white sturgeon ................. 19

Figure 13. Photographs of histological sections of medium (spiral) intestine of juvenile white sturgeon ...................... 20

Figure 14. Photographs of histological sections of medium (spiral) intestine of juvenile white sturgeon..................... 21

\section{Tables}

Table 1. Characteristics of the 37 white sturgeon captured from Lake Roosevelt in October 2008 with an assessment of gut section fullness index (SFI) and weights of contents

Table 2. Lengths and weights, weight of slag in gut, and intestinal histopathology scores for 14 white sturgeon captured from Lake Roosevelt in October 2008, and comparison with 7 white sturgeon obtained from the CERC ..... 24 


\section{Conversion Factors, Datum, and List of Abbreviations}

\section{Conversion Factors}

\begin{tabular}{lll}
\hline \multicolumn{1}{c}{ Multiply } & By & \multicolumn{1}{c}{ To obtain } \\
\hline centimeter $(\mathrm{cm})$ & Length & \\
millimeter $(\mathrm{mm})$ & 0.3937 & inch (in.) \\
meter $(\mathrm{m})$ & 0.03937 & inch (in.) \\
kilometer $(\mathrm{km})$ & 3.281 & foot (ft) \\
kilometer $(\mathrm{km})$ & 0.6214 & mile (mi) \\
& 0.5400 & mile, nautical (nmi) \\
\hline square meter $\left(\mathrm{m}^{2}\right)$ & Area & \\
\hline & 0.0002471 & acre \\
\hline cubic centimeter $\left(\mathrm{cm}^{3}\right)$ & Volume & \\
\hline & 0.06102 & cubic inch (in $\left.{ }^{3}\right)$ \\
\hline milligrams $(\mathrm{mg})$ & Mass & \\
gram $(\mathrm{g})$ & 0.00003527 & ounce, avoirdupois (oz) \\
kilogram $(\mathrm{kg})$ & 0.03527 & ounce, avoirdupois (oz) \\
metric tons & 2.205 & pound, avoirdupois (lb) \\
\hline
\end{tabular}

Temperature in degrees Celsius $\left({ }^{\circ} \mathrm{C}\right)$ may be converted to degrees Fahrenheit $\left({ }^{\circ} \mathrm{F}\right)$ as follows:

${ }^{\circ} \mathrm{F}=\left(1.8 x^{\circ} \mathrm{C}\right)+32$.

\section{Datum}

Horizontal coordinate information is referenced to the North American Datum of 1983 (NAD 83)

\section{List of Abbreviations}

CERC Columbia Environmental Research Center

FL Fork Length

PIT Passive Integrated Transponder

SD Standard Deviation

USEPA U.S. Environmental Protection Agency

USGS U.S. Geological Survey 


\title{
Characterization of the Contents and Histology of the Gastrointestinal Tracts of White Sturgeon (Acipenser transmontanus) Captured from Upper Lake Roosevelt, Washington, October 2008
}

\author{
By Michael J. Parsley, Bjorn K. van der Leeuw, and Diane G. Elliott
}

\begin{abstract}
The gastrointestinal tracts of 37 juvenile white sturgeon (Acipenser transmontanus) captured from the upper part of Lake Roosevelt during October 2008, were examined to identify prey taxa and to determine if the fish were consuming smelter slag along with other sediments. Histological examination of the gastrointestinal tract tissues and comparison with similar tissues from hatchery-reared fish also was performed. The contents of the gastro-intestinal tracts (guts) indicated that white sturgeon were actively foraging on various benthic invertebrates and the diet was quite diverse, with more than 50 percent of the fish feeding on five or more different taxa. Slag was present in 76 percent of the guts examined. Although not all guts contained slag particles, larger fish tended to have greater amounts of slag in their guts. Histology of the gut tissues showed the presence of a chronic inflammatory response, and the severity of the response had a significant positive correlation $(P=0.01)$ with fish length and weight suggesting that the inflammation represented a response to long-term exposure to one or more stressors. However, additional work is needed to determine if the physical or chemical properties of slag contributed to this response.

Introduction

The white sturgeon population in Franklin D. Roosevelt Lake (commonly known as Lake Roosevelt), a reservoir of the Columbia River in northeastern Washington State, consists primarily of aging fish and the number of fish is gradually declining as fish die and are not replaced by wild (nonhatchery reared) juvenile fish. Newly hatched wild sturgeon are readily captured in the upper riverine reaches of Lake Roosevelt (Howell and McLellan, 2009); however, recent assessments of the sturgeon population structure indicate that few wild juvenile white sturgeon survive to reach sexual maturity, and the population is threatened with extinction unless rigorous restoration efforts are implemented (Upper Columbia White Sturgeon Recovery Initiative, 2002). These fish spawn in the upper riverine reservoir reaches of Lake Roosevelt (Howell and McLellan, 2009) and at several locations upstream of the International border (fig. 1). White sturgeon juveniles and adults can be found throughout the upper reaches of Lake Roosevelt and the Columbia River (Upper Columbia White Sturgeon Recovery Initiative, 2002; Howell and McLellan, 2009).
\end{abstract}


White sturgeons are benthic oriented feeders with a diverse diet. Previous studies of the diet of white sturgeon in other areas show that as these fish forage, they ingest sediments and non-digestible material including the shells, carapaces, and exoskeletons of prey (Schreiber, 1962; McCabe and others, 1993; Muir and others, 2000; Romano and others, 2002). These studies provided information on types of food items consumed, but did not quantify the proportion of the diet that is non-digestible, which is important when knowledge of the relative importance and energetic value of prey is needed. The goals of this study were (1) to characterize the prey taxa of juvenile white sturgeon residing in the upper reservoir and riverine part of Lake Roosevelt; (2) to determine if the fish were consuming smelter slag, a byproduct of ore processing, along with other sediments during foraging; and (3) to investigate what effect the consumption of slag may have on tissues of the gastrointestinal tract.

Morphological investigations of the alimentary canal of white sturgeon suggest that the structure of the esophagus and stomach is well suited to maximize caloric intake while passing non-digestible material. The thick mucosa may serve to protect the underlying layers from physical damage during trituration in the gastric region, while the spiral valve and pyloric caecum increase the effective length and hence absorptive capacity of the intestine (Buddington and Doroshov, 1986).

An estimated 12.1-14.3 million metric tons of smelter slag was discharged into the Columbia River prior to 1995 (U.S. Environmental Protection Agency, 2003). Much of this slag has been unevenly deposited in Lake Roosevelt in the reach upstream of Kettle Falls. Some large deposits of slag like the one at Black Sand Beach (fig. 1) are well known but the location of most of the deposited slag material is not well documented. It has been hypothesized, based on grain-size distribution and analysis of channel cross-sectional area, that most of the slag has been deposited in the pre-reservoir river channel area near or upstream of Marcus Flats (fig. 1; U.S. Environmental Protection Agency, 2006). However, other deposits of slag occur throughout the river and reservoir upstream of Grand Coulee Dam. During periods of low reservoir stage, slag has been observed among the interstitial sediments of exposed gravel bars. When inundated during the white sturgeon spawning period, these gravel bars are believed to be habitat for newly hatched white sturgeon.

Causal effects of slag on the white sturgeon population are unknown, but there are reasons to suspect some effect. In the riverine reach of Lake Roosevelt, concentrations of copper and zinc in bed sediments can reach levels of 10,000 and $30,000 \mathrm{mg} / \mathrm{kg}$ due to presence of smelter slag. Recent studies demonstrated that copper, along with other metals, could be mobilized from slag containing sediments (Paulson and Cox, 2007). In a separate study, copper was determined to be highly toxic to 30-day-old white sturgeon with 96-h LC50 concentrations ranging from 3 to $5 \mu \mathrm{g} \mathrm{Cu} / \mathrm{L}$ (Ed Little, U.S. Geological Survey, unpub. data, 2009). Because white sturgeons commonly ingest sediment, fish foraging in slagcontaminated sediments likely have slag particles in their guts. The physical properties of slag particles, which are sharp, glassy, and angular (fig. 2), may have detrimental effects on the intricate tissues lining the gut. These studies suggest that slag may have adverse effects on white sturgeon. Resource managers for the Lake Roosevelt ecosystem need additional information about the factors and processes responsible for the decrease in abundance of the white sturgeon and any relation to the presence of smelter slag. 


\section{Approach and Methods}

\section{White Sturgeon Capture and Gut Collection}

The gastrointestinal tracts (hereafter referred to as guts) of 37 juvenile white sturgeon were obtained during October 21-24, 2008. The fish were captured by the Washington Department of Fish and Wildlife during their annual white sturgeon stock assessment program in Lake Roosevelt. Benthic gillnets were fished overnight and upon retrieval white sturgeon were measured for fork length (FL; nearest millimeter) and weighed with a 4-kg capacity electronic balance accurate to $\pm 2 \mathrm{~g}$. For our analysis, we selected only hatchery-origin juvenile fish, identified by the presence of a Passive Integrated Transponder (PIT) tag, because recovery efforts that are underway for the species seek to preserve naturally produced white sturgeon. The fish we analyzed were captured from 13 locations (fig. 3 ) between river kilometers 1,120 and 1,170. The fish were killed by severing the spinal cord immediately posterior and dorsal to the operculum (in the nape or neck area) with a sharp knife. We then used a scalpel to slit each fish ventrally starting from alongside the anus to the base of the gill arches and removed the gastrointestinal tract from the body cavity by making cuts at the anus, the esophagus, and at the connection to the physostomus air bladder. Twenty-one guts were injected intraluminally with Carson's modified Millonig phosphate-buffered formalin (Poly/LEM) solution (Carson and others, 1973) for histological analysis. We used a syringe and needle to inject several cubic centimeters of the fixative into the gastrointestinal tract at multiple places and sealed the gut and a sample label in a container with additional Poly/LEM solution. The other 16 guts were sealed in plastic sample bags and placed in a cooler on dry ice. We transported all samples to the laboratory for processing and kept frozen samples at $-80{ }^{\circ} \mathrm{C}$.

\section{Gut Processing}

In the laboratory, we removed each gut from the sample container and rinsed the original container to ensure no material remained. We sectioned guts that had been injected with Poly/LEM solution at several locations and all tissues were rinsed to remove the contents. Frozen guts were thawed and a longitudinal cut with scissors or a scalpel was made along the length of the gut to expose the contents. We assessed fullness of each gut segment (duodenum, jejunum, and rectum, or foregut, midgut, and hindgut) following Young and Davis (1990) where: $0=$ empty; $1=$ at least some form of contents; 2 = less than half-full; 3 = half-full; 4 = greater than half-full; and $5=$ distended. The gut lining was washed with 70-percent ethanol while working over a sieve to recover all contents, which were then placed in a container with 70-percent ethanol. For the frozen samples, this step served to coagulate the digestive secretions and permitted relatively easy separation of the contents. We then scanned the gut contents under a dissecting microscope and identified food items observed to the lowest practical taxonomic level.

We obtained the dry weight of the contents by filtering the material through a Buchner Funnel lined with Grade $41(20-\mu \mathrm{m}$ nominal pore size) ashless filter paper. Filter papers and aluminum weighing pans were pre-dried and weighed to the nearest $0.01 \mathrm{mg}$ before use. We supplied a vacuum to the Buchner Funnel using an aspirator attached to a water supply. Filter papers and contents were then placed back into the weighing pans and dried at $60{ }^{\circ} \mathrm{C}$ for $48 \mathrm{~h}$. A weight was taken at this time and the contents, filter, and pan were returned to the drying oven for another $4 \mathrm{~h}$. If the two weights were within 1 percent, we deemed the sample to be sufficiently dried and used the average of the two weights to represent dried weight of the contents. 
We determined the ash free dry weight of the contents by combusting in a muffle furnace at $500{ }^{\circ} \mathrm{C}$ for $2 \mathrm{~h}$ and weighing to the nearest $0.01 \mathrm{mg}$. Combusted samples were then placed in airtight vials.

\section{Slag Separation}

The ashes from each gut were visually examined under a dissecting microscope and slag particles (fig. 2) were separated and removed by manually picking particles with fine forceps. The ashes were stirred frequently to locate all slag particles. Slag particles were readily distinguished from natural sediment grains of the Columbia River by a combination of distinctive morphology and physical features (Cox and others, 2004). Slag particles are sand size or smaller, black in color, and often have an iridescent sheen (fig. 2). The surface texture of relatively unweathered particles is smooth, glassy, with a lustrous appearance and the surface of weathered grains has a dull-etched appearance. Slag particles have a distinctive morphology resulting from the combination of rounded and angular features often with needle-like projections, conchoidal fracture patterns, and small cavities or vugs. Slag particles from each gut were then weighed in aggregate to the nearest $0.01 \mathrm{mg}$.

\section{Tissue Histology}

Gut tissues obtained from fish captured from Lake Roosevelt were visually compared to gut tissues obtained from 18-month-old white sturgeon reared at the U.S. Geological Survey (USGS) Columbia Environmental Research Center (CERC), Columbia, Missouri. Preservation of gut tissues of the CERC fish was identical to those for Lake Roosevelt fish. All preserved tissues were dissected into five regions - esophagus (proximal, medium, and distal), stomach (proximal and pyloric), proximal intestine, medium intestine and spiral valve, and posterior (distal) intestine - then rinsed with 70-percent ethanol to remove the gut contents. Some samples included accessory organs, such as the physostomus swim bladder, pyloric cecum, pancreas, spleen, and liver. Tissues were processed through a graded series of ethanol and infiltrated with paraffin. Sections $5 \mu \mathrm{m}$ in thickness were cut with a microtome and stained with hematoxylin-eosin (HE) for histological examination by light microscopy. Evaluations included distribution (scale 0-3; scored as none, focal, multi-focal, or diffuse) and severity (scale 0-4; scored as none, minimal, mild, moderate, or severe) of pathological changes observed in gastrointestinal tissues. The amount (weight) of slag present in gastrointestinal tracts of each Lake Roosevelt sturgeon was unknown to the histopathologist at the time that the histological examinations were done. The Mann-Whitney Test was used to compare median histopathology scores between two groups of fish, and Spearman's rank correlation procedure was used to test for correlation between histopathology scores and other parameters (InStat 3 software, GraphPad, La Jolla, California). 


\section{White Sturgeon Gut Contents}

The 37 juvenile white sturgeons captured were from hatchery brood years 2004 to 2007 (table 1). Because hatchery origin juvenile white sturgeons were released after 1 year of rearing, these fish had been residing in Lake Roosevelt for 1-4 growing seasons prior to capture. The fish ranged in length from 287 to $647 \mathrm{~mm}$ FL (fig. 4) and had a mean condition factor (Fulton's k) of 0.67 (SD $= \pm 0.08$; table 1).

All guts contained some material and the prey primarily was benthic in origin. The taxa detected most frequently among the fish included isopods (Isopoda), larval chironomids (Diptera), clams (Pelecypoda), and larval caddisflies (Trichoptera) (fig. 5). Bryozoan statoblasts, woody debris, and bits of vegetation were common among fish and were likely ingested along with prey. The number of food categories detected in individual guts ranged from 1 to 11 (fig. 6) indicating a diverse diet characteristic of fish feeding opportunistically. Gut fullness indexes varied among gut segments for individual fish (table 1). The occurrence of foregut fullness indexes ranging from empty to distended suggests that foraging was not synchronous among individuals and was discontinuous over time. Gut contents dry weight and weight lost during combustion increased with fish size (figs. 7 and 8). The non-combustible ash proportion of the diet averaged 58 percent (range $=9.3-88.8$ percent; fig. 9) indicating that much of the material consumed during foraging will be passed as feces.

\section{Slag}

Slag was present in 28 (76 percent) of the guts. The amount present varied from only a few particles to $0.2672 \mathrm{~g}$ (table 1) and generally increased with fish size (fig. 10), although some of the larger fish had very little slag present in the gut contents. In one gut, the weight of slag comprised 10.4 percent of the weight of the non-combustible gut contents. Although slag was not present in every gut, it was detected in guts collected from river kilometers 1,129 to 1,170 (fig. 11). The two guts collected farthest downstream (river kilometer 1,120) did not contain slag.

\section{Histology}

Tissues from guts obtained from 14 fish captured from Lake Roosevelt (table 1) were compared with seven juvenile (18-month-old) white sturgeon reared at the USGS CERC, Columbia, Missouri (546-655 mm FL, weight 875-1,520 g). Gastrointestinal tracts of seven additional fish from Lake Roosevelt were not examined because the tissues were incompletely preserved, resulting in autolysis of gastrointestinal tissues. The gastrointestinal tracts of the juvenile hatchery white sturgeon from CERC appeared to be mostly normal (figs. 12A, 13A, and 14A). Aggregations of lymphocytes as well as scattered lymphocytes were common in the connective tissue of the gastrointestinal tract, and scattered lymphocytes also were observed in the gastrointestinal epithelium (figs. $12 A$ and $14 A$ ). Lymphoid cell aggregates and follicles were present in several areas but were universally present in the connective tissue of the central typhlosole of the spiral valve (fig. 13A); similar lymphoid follicles were observed in all Lake Roosevelt fish (fig. 13B). In contrast to the CERC fish, however, all Lake Roosevelt fish showed a multifocal to diffuse increase in lymphocytes and other inflammatory cells, such as eosinophilic granular cells and macrophages throughout the gastrointestinal tract. Chronic inflammation in the Lake Roosevelt fish was particularly prominent in the mucosa (epithelium and the underlying lamina propria connective tissue layer) of the pyloric cecum, the proximal (straight) intestine (fig. 12B) and the medium (spiral) intestine (figs. $13 B$ and 14B). Whereas the enterocytes (intestinal absorptive epithelial cells) in the CERC fish showed a regular simple columnar morphology with basally oriented 
nuclei, the intestinal epithelium in the Lake Roosevelt fish often exhibited a thickened appearance, with irregular stratification of enterocytes and an apparent reduction in polarity of the enterocyte nuclei. In addition, an increase in cells showing signs of apoptosis (programmed cell death) was evident in the intestinal epithelium of the Lake Roosevelt fish. Small sections of unidentified metazoans (probably Platyhelminthes) were observed in the lumina of the proximal intestines of two Lake Roosevelt fish. A single section was observed in each of the fish, and minor compression of the intestinal epithelium was the only change associated with the presence of the parasites (observed in one fish only).

Because histopathological changes were most prominent in the pyloric cecum, straight intestine, and spiral intestine of the Lake Roosevelt fish, an intestinal histopathology score was calculated for each fish (both CERC and Lake Roosevelt fish) based on the changes observed in these areas of the intestine. Distribution and severity scores were obtained for infiltration of lymphocytic cells and other inflammatory cells in the lamina propria and intestinal epithelium, stratification and loss of polarity of epithelial enterocytes, and apoptosis of cells in the epithelium. The lymphoid follicles that were universally present in certain areas of the intestine of the CERC and Lake Roosevelt fish were considered normal morphological features and were not counted in the histopathology scores. Scores for the pathological changes observed in each of the three areas of the intestine were added to obtain an overall intestinal histopathology score for each fish (table 2). The intestinal histopathology scores for the Lake Roosevelt fish (mean 68.9 $\pm 10.9 \mathrm{SD}$; table 2$)$ were significantly higher $(P<0.0001)$ than the scores for the CERC fish (mean 27.2 $\pm 2.0 \mathrm{SD}$ ). There was no significant difference $(P=0.44)$ in intestinal histopathology scores for Lake Roosevelt fish with slag detected in the gut (mean 67.4 \pm 12.0 SD) compared with fish in which no slag was detected in the gut (mean 72.4 7.2 SD). Among the nine fish in which slag was detected in the guts, there was a trend toward higher intestinal histopathology scores in fish with lower amounts of detected slag, but the trend was not quite significant $(P=0.06)$. There was, however, significant positive correlation between intestinal histopathology scores and fish fork length $(P=0.01)$, and fish weight $(P=0.01)$ for the Lake Roosevelt fish, but not for the CERC fish $(P \geq 0.40)$.

\section{Discussion}

The results from our study show the importance of benthic foraging for invertebrates to juvenile white sturgeon in the upper reaches of Lake Roosevelt. Although our characterization of the diet was qualitative, the majority of fish examined had consumed isopods (Isopoda), clams (Pelecypoda), and aquatic insects, including larval chironomids (Diptera) and caddisflies (Trichoptera). Howell and McLellan (2009) also reported that insects (primarily Trichoptera) were the most abundant prey in the diet of 15 juvenile white sturgeon from Lake Roosevelt and that the fish consumed taxa similar to this study. These items are an important component of the diet of many species of sturgeon. Modde and Schmulbach (1977) determined that juvenile shovelnose sturgeon (Scaphirhynchus platorynchus) fed primarily on isopods, specifically Asellus spp., from September through December. Wanner and others (2007) determined that chironomids occurred more often than any other prey type in juveniles of shovelnose and pallid sturgeon (S. albus) particularly in autumn. Although the estuarine amphipod Corophium salmonis was the most important prey item for juvenile white sturgeon captured from the unimpounded Columbia River downstream of Bonneville Dam (McCabe and others, 1993), this species is not found in Lake Roosevelt. The white sturgeon in Lake Roosevelt made use of a broad forage base during autumn, with more than 50 percent of the fish having fed on five or more different kinds of forage. 
The clumped distribution of the guts analyzed were a result of the need to obtain white sturgeon for a number of analytical tests in a limited time under high uncertainty of catches. Fish were processed in a first-come basis. This precluded a statistical assessment of diet or consumption of slag among sample sites.

The condition factor of the fish we captured (mean $=0.67 ; \mathrm{SD}= \pm 0.08$ ) is comparable to that of juvenile white sturgeon of a similar size $(\geq 70 \mathrm{~cm} \mathrm{FL})$ from the Columbia River downstream of Bonneville Dam (mean $=0.68 ; \mathrm{SD}= \pm 0.08$; McCabe and Hinton, 1991), which is considered to be one of the most productive reaches for white sturgeon. This suggests that the metabolic and caloric requirements for fish of this size are being met in this section of Lake Roosevelt.

Slag was consumed along with food and non-food items including other sediments. The high non-digestible component of the contents (fig. 9) suggests that much of the material consumed must be passed in feces. Studies of sturgeon movements in Lake Roosevelt (Howell and McClellan, 2009) have shown that individual fish are capable of making extensive seasonal and local movements and that most white sturgeon adults and hatchery juveniles overwinter between Rickey Point (river kilometer 1,119) and Marcus Island (river kilometer 1,141). It is probable, therefore, that most white sturgeon in Lake Roosevelt consume and routinely pass slag in feces during their lives. The foraging activity of white sturgeon likely exposes previously buried slag particles and the consumption and subsequent passing of slag as feces results in the redistribution of slag within Lake Roosevelt. Feeding pits observed on tidal flats of Willapa Bay, Washington, and attributed to foraging by white or green sturgeon (A. medirostris) were $30-60 \mathrm{~cm}$ in diameter and ranged from 1.6 to 6.4 pits per $100 \mathrm{~m}^{2}$ (Dumbauld and others, 2008). The potential for exposure and redistribution of slag particles by white sturgeon will increase as restoration efforts increase the number and size of white sturgeon in Lake Roosevelt.

No signs of obvious acute physical trauma to gut tissues were observed, suggesting that white sturgeon readily pass slag particles and other non-digestible items as feces. This was not unexpected, as the sturgeon gut is adapted to passing non-digestible exoskeletons and shells from invertebrates.

However, results of histological analysis of the Lake Roosevelt sturgeon showed increased chronic inflammation in the gastrointestinal tracts of all those fish in comparison to the hatchery-reared white sturgeon from CERC. Increased inflammation also was observed in kidney, liver, and gill tissues of Lake Roosevelt juvenile white sturgeon sampled in 2008 compared to the same tissues examined from CERC juvenile white sturgeon (Elizabeth MacConnell, Headwaters Fish Pathology, LLC, Bozeman, Montana, written commun. 2009, 2010). The individual Lake Roosevelt fish (fish \#LR15, table 2) that showed the highest severity of intestinal inflammation in the present study also had severe granulomatous inflammation with lymphocytic infiltrate in the liver (Elizabeth MacConnell, Headwaters Fish Pathology, LLC, written commun. 2009, 2010).

Observations of more intense inflammatory responses in tissues of wild white sturgeon in contrast to those from hatchery sturgeon have been previously described (Foster and others, 2001), and likely reflect increased exposure of fish to infectious agents and other stressors outside of the controlled hatchery environment. Intestinal changes such as inflammatory cell infiltration, increased apoptosis, and loss of polarity of enterocyte nuclei have been reported in various fish species exposed to various stressors, including nutritional factors (Baeverfjord and Krogdahl, 1996; Domeneghini and others, 2002), xenobiotocs (Crespo and others, 1986; Lundebye and others, 1999; Berntssen and others, 2001; Kamunde and others, 2001; Clearwater and others, 2002), and parasites and other pathogens (Weisel, 1973; Ferguson, 2006). No parasites or other pathogens were associated with the chronic intestinal inflammation observed in the Lake Roosevelt fish, and the possible causes of this inflammation were not identified in the study. Although no significant relation between intestinal inflammation and the presence or amount of slag in the guts was detected, the one-time measurement of the weight of slag in 
the gut contents of a fish may not have been representative of the amount of slag consumed during the entire Lake Roosevelt residence of that fish. Thus, it is uncertain whether the physical or chemical properties of slag may have contributed to the histopathological changes observed in the gut tissues. The significant positive correlations between fish size (length and weight) and the severity of the inflammatory changes observed supports the hypothesis that the inflammation represented a response to long-term exposure to one or more stressors.

\section{Suggestions for Future Studies}

The food habits information presented here are important but have limited value for depictions of ecological food webs. Diet information is needed for all sizes of white sturgeon collected over an entire growing season. Future studies of the diet of white sturgeon in Lake Roosevelt should incorporate spatial and temporal components into sampling strategies and should consider obtaining guts from smaller and larger fish. A statistically robust sampling design should be developed that would address gear bias inherent in capturing a broad size range of white sturgeon. Stable isotope analysis could provide a means to evaluate changes in river habitats, seasonal changes in prey availability or feeding habitats, and determination of energy origination points (Angradi, 1994; Sierszen and others, 1996; Fisher and others, 2001). Using dietary and isotopic approaches to create an energy transfer food web can in turn be supported by biological observations and chemical assessments (Fisher and others, 2001). Bioenergetics modeling could then provide a means to estimate the growth potential of white sturgeon.

Bioenergetics modeling approaches also would require studies of maximum consumption, gut evacuation rates, and seasonal foraging behaviors. Knowledge of these also could provide a means to estimate the ability of a single fish or the population to expose or redistribute slag over time. Maximum consumption equations typically are estimated by laboratory study, however, they also could be obtained by weighing the foregut contents of full and distended stomachs.

For comparison of histopathological changes with the Lake Roosevelt fish, guts and tissue samples should be obtained from white sturgeon foraging in slag-free river reaches. Nevertheless, because sturgeon in Lake Roosevelt are likely exposed to a variety of stressors, determination of the possible contribution of the physical or chemical properties of slag to chronic intestinal inflammation also may require laboratory feeding studies of hatchery-reared sturgeon. Laboratory studies comparing the growth and condition of juvenile white sturgeon fed food mixed with slag and food without slag should be conducted. However, laboratory studies may not adequately emulate the effects of a natural diet on the gastrointestinal tissues.

Further research should be conducted to estimate current prey availability and the effects that contaminants and reservoir operations have on prey availability. Nener (1992) and Besser and others (2008) show that benthic invertebrate abundance and survival are reduced in contaminated sediments containing slag in upper Lake Roosevelt. Besser and others (2008) also show bioaccumulation of copper and other metals in benthic invertebrates. Declines in abundance of prey of suitable size, changes in prey community composition because of contaminated sediments, invasive species, reservoir operations, and potentially toxic prey could lead to reduced productivity of white sturgeon in Lake Roosevelt. 


\section{Conclusions}

In this study, we determined that the autumn diet of juvenile white sturgeon in upper Lake Roosevelt primarily is composed of benthic invertebrates and that much of the material consumed is comprised of sediments and non-digestible material that must be passed in feces. We detected smelter slag particles in 76 percent of the gastrointestinal tracts examined. The condition factor of Lake Roosevelt white sturgeon is similar to the condition factor of same-sized white sturgeon from the unimpounded Columbia River downstream of Bonneville Dam where the white sturgeon population is considered to be the most productive within the species' range. However, Lake Roosevelt white sturgeon exhibited increased chronic inflammation of gastrointestinal tract tissues compared to hatchery-reared white sturgeon. Although no significant relation between intestinal inflammation and the presence or amount of slag in the guts was detected, the one-time measurement of the weight of slag in the gut contents of a fish may not have been representative of the amount of slag consumed during the entire Lake Roosevelt residence of that fish. Thus, it is uncertain whether the physical or chemical properties of slag may have contributed to the histopathological changes observed in the gut tissues. The severity of the inflammatory changes observed in the tissues increased with fish size, supporting the hypothesis that the inflammation represented a response of Lake Roosevelt white sturgeon to long-term exposure to one or more stressors.

\section{Acknowledgments}

The authors of this report would like to thank Timothy Kiser, U.S. Fish and Wildlife Service, Jason McLellan, Mattew Howell, and Charlee Capaul, Washington Department of Fish and Wildlife, and Brendan Dowling, Washington Department of Ecology, for their hard work, dedication, and attention to detail during the fish sampling. They were crucial to the success of this project. We would also like to thank Carla Conway, Patrick Moran, and Stephen Cox of the U.S. Geological Survey for their assistance.

\section{References Cited}

Angradi, T.R., 1994, Trophic linkages in the lower Colorado River-Multiple stable isotope evidence: Journal of the North American Benthological Society, v. 13, p. 479-495.

Baeverfjord, G., and Krogdahl, Å., 1996, Development and regression of soybean meal induced enteritis in Atlantic salmon, Salmo salar L., distal intestine-A comparison with the intestines of fasted fish: Journal of Fish Diseases, v. 19, p. 375-387.

Berntssen, M.H.G., Aspholm, O.Ø., Hylland, K., Wendelaar Bonga, S.E., and Lundebye, A.-K., 2001, Tissue metallothionein, apoptosis, and cell proliferation responses in Atlantic salmon (Salmo salar L.) parr fed elevated dietary cadmium: Comparative Biochemistry and Physiology Part C, v. 128, p. 299310.

Besser, J.M., Brumbaugh, W.G., Ivey, C.D., Ingersoll, C.G., and Moran, P.W., 2008, Biological and chemical characterization of metal bioavailability in sediments from Lake Roosevelt, Columbia River, Washington, USA: Archives of Environmental Contamination and Toxicology, v. 54, p. 557-570.

Buddington, R.K., and Doroshov, S.I., 1986, Structural and functional relations of the white sturgeon alimentary canal (Acipenser transmontanus): Journal of Morphology, v. 190, p. 201-213.

Carson, F.L., Martin, J.H., and Lynn, J.A., 1973, Formalin fixation for electron microscopy-A reevaluation. American Journal of Clinical Pathology, v. 59, p. 365-373.

Clearwater, S.J., Farag, A.M., and Meyer, J.S., 2002, Bioavailability and toxicity of dietborne copper and zinc to fish: Comparative Biochemistry and Physiology Part C, v. 132, p. 269-313. 
Cox, S.E., Bell, P.R., Lowther, J.S., and VanMetre, P.C., 2004, Vertical distribution of trace-element concentrations and occurrence of metallurgical slag particles in accumulated bed sediments of Lake Roosevelt, Washington, September 2002: U.S. Geological Survey Scientific Investigations Report 2004-5090, $70 \mathrm{p}$.

Crespo, S., Nonnotte, D., Colin, A., Leray, C., Nonnotte, L., and Aubree, A., 1986, Morphological and functional alterations induced in trout intestine by dietary cadmium and lead: Journal of Fish Biology, v. 28, p. $69-80$.

Domeneghini, C., Radaelli, G., Bosi, G., Arrighi, S., Di Giancamillo, A., Pazzaglia, M., and Mascarello, F., 2002, Morphological and histochemical differences in the structure of the alimentary canal in feeding and runt (feed deprived) white sturgeons (Acipenser transmontanus): Journal of Applied Ichthyology, v. 18, p. 341-346.

Dumbauld, B.R., Holden, D.L., and Langness, O.P., 2008, Do sturgeon limit burrowing shrimp populations in Pacific Northwest Estuaries?: Environmental Biology of Fishes, v. 83, p. 283-296.

Ferguson, H.W., 2006, Systemic pathology of fish, Second ed,: London, Scotian Press.

Fisher, S.J., Brown, M.L., and Willis, D.W., 2001, Temporal food web variability in an upper Missouri River backwater-Energy origination points and transfer mechanisms: Ecology of Freshwater Fish, v. 10, p. 154-167.

Foster, E.P., Fitzpatrick, M.S., Feist, G.W., Schreck, C.B., Yates, J., Spitzbergen, J.M., and Heidel, J.R., 2001, Plasma androgen correlation, EROD induction, reduced condition factor, and the occurrence of organochlorine pollutants in reproductively immature white sturgeon (Acipenser transmontanus) from the Columbia River, USA: Archives of Environmental Contamination and Toxicology, v. 41, p. 182191.

Howell, M.D., and McLellan, J.G., 2009, Lake Roosevelt white sturgeon recovery project annual progress report, April 2006-March 2007: Portland, Oreg., Bonneville Power Administration, accessed February 2010, at http://www.efw.bpa.gov/searchpublications/\#.

Kamunde, C.N., Grosell, M., Lott, J.N.A., and Wood, C.M., 2001, Copper metabolism and gut morphology in rainbow trout (Oncorhynchus mykiss) during chronic sublethal dietary copper exposure: Canadian Journal of Fisheries and Aquatic Sciences, v. 58, p. 293-305.

Lundebye, A.-K., Berntssen, M.H.G., Wendelaar Bonga, S.E., and Maage, A., 1999, Biochemical and physiological responses in Atlantic salmon (Salmo salar) following dietary exposure to copper and cadmium: Marine Pollution Bulletin, v. 39, p. 137-144.

McCabe, G.T., and Hinton, S.A., 1991, Report D in Nigro, A.A., ed., Status and habitat requirements of the white sturgeon populations in the Columbia River downstream from McNary Dam: Portland, Oreg., Annual Progress Report to the Bonneville Power Administration, April 1990-March 1991, p. 145-180.

McCabe, G.T., Jr., Emmett, R.L., and Hinton, S.A., 1993, Feeding ecology of juvenile white sturgeon (Acipenser transmontanus) in the lower Columbia River: Northwest Science, v. 63, p. 170-180.

Modde, T., and Schmulbach, J.C., 1977, Food and feeding behavior of the shovelnose sturgeon, Scaphirhynchus platorynchus, in the unchannelized Missouri River, South Dakota: Transactions of the American Fisheries Society, v. 106, p. 602-608.

Muir, W.D., McCabe, G.T., Jr., Parsley, M.J., and Hinton, S.A., 2000, Diet of first feeding larval and young-of-the-year white sturgeon in the lower Columbia River: Northwest Science, v. 74, p. 25-33. Nener, J., 1992, Survival and water-quality results of bioassays on five species of aquatic organisms exposed to slag from Cominco's Trail operation: Vancouver, British Columbia, Canada, Fisheries and Oceans Canada, 20 p. plus tables and appendixes. 
Paulson, A.J. and Cox, S.E., 2007. Release of elements to natural water from sediments of Lake Roosevelt, Washington, USA: Environmental Toxicology and Chemistry v. 26, p. 2550-2559. Romano, M.D., Rien, T.A., and Ward, D.L., 2002, Seasonal presence and diet of white sturgeon in three proposed in-river, deep-water dredge spoil disposal sites in the lower Columbia River: Columbia River Channel Improvement Project Final Supplemental Integrated Feasibility Report and Environmental Impact Statement, Exhibit K-1, U.S. Army Corps of Engineers, Portland District, p. 523.

Schreiber, M.R., 1962, Observations on the food habits of juvenile white sturgeon: California Fish and Game, v. 48, no. 1, p. 79-80.

Sierszen, M.E., Keough, J.R., and Hagley, C.A., 1996, Trophic analysis of ruffe (Gymnocephalus cernuus) and white perch (Morone americana) in a Lake Superior coastal food web, using stable isotope techniques: Journal of Great Lakes Research, v. 22, p. 436-443.

Upper Columbia River White Sturgeon Recovery Initiative, 2002, Recovery efforts: Upper Columbia River White Sturgeon Recovery Plan website, accessed June 2010, at http://uppercolumbiasturgeon.org/RecoveryEfforts/Rec-RecPlan.html.

U.S. Environmental Protection Agency, 2003, Upper Columbia River Expanded Site Investigation Report, northeast Washington: TDD: 01-02-0028, U.S. Environmental Protection Agency Superfund Technical Assessment and Response Team, variously paginated.

U.S. Environmental Protection Agency, 2006, Phase I sediment sampling data evaluation-Upper Columbia River site, CERCLA RI/FS, Draft final: Washington, D.C., U.S. Environmental Protection Agency, prepared by CH2M HILL and Ecology and Environment Inc. under Contract No. 68-57-0401 .

Wanner, G.A., Shuman, D.A., and Willis, D.W., 2007, Food habits of juvenile pallid sturgeon and adult shovelnose sturgeon in the Missouri River downstream of Fort Randall Dam, South Dakota: Journal of Freshwater Ecology, v. 22, p. 81-92.

Weisel, G.F., 1973, Anatomy and histology of the digestive system of the paddlefish (Polydon spathula): Journal of Morphology, v. 140, p. 243-256.

Young, J.W., and Davis, T.L.O., 1990, Feeding ecology of larvae of southern bluefin, albacore and skipjack tunas (Pisces: Scombridae) in the eastern Indian Ocean: Marine Ecology Progress Series, v. 61, p. 17-29. 


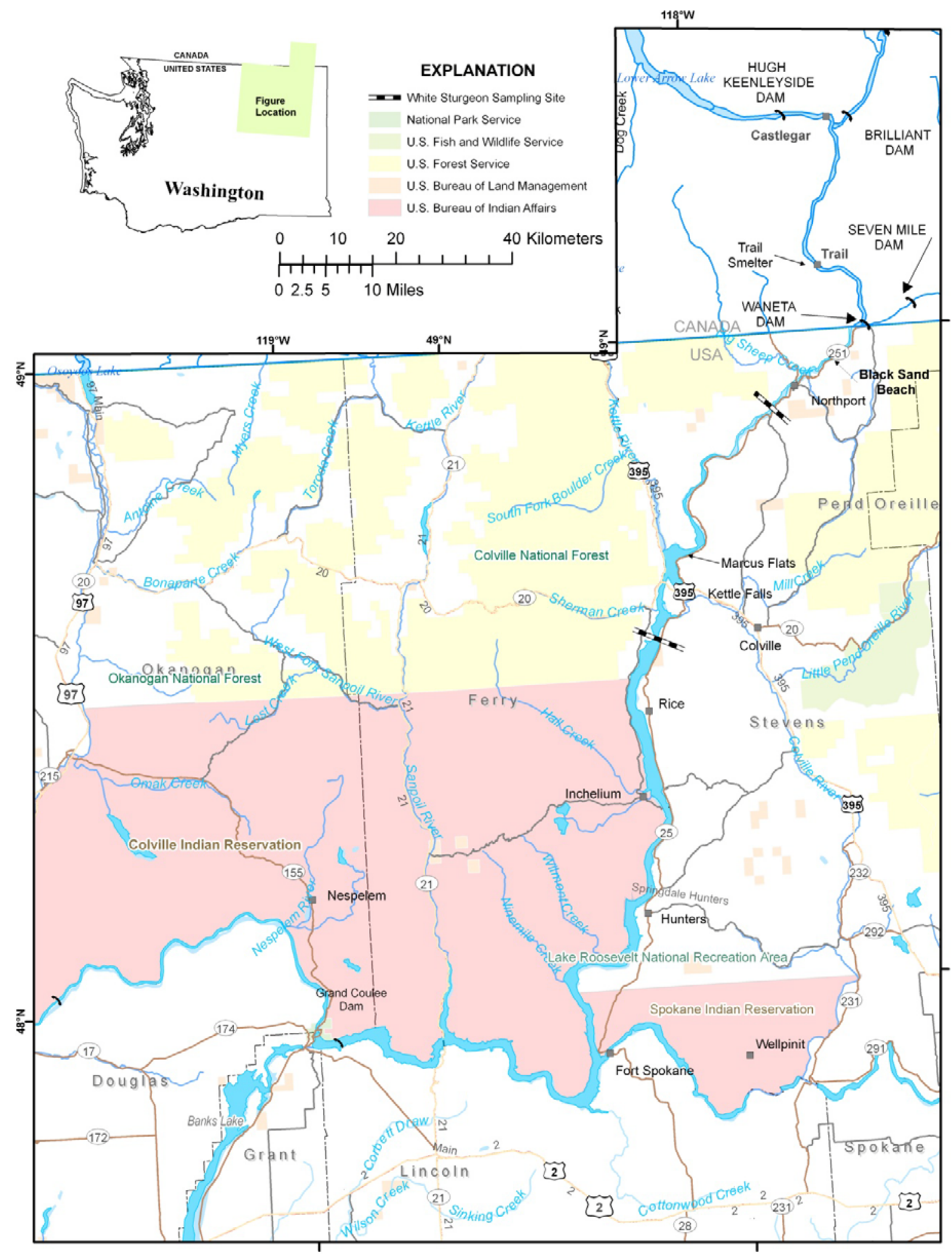

Figure 1. Map showing Columbia River Basin and the Lake Roosevelt study area. 

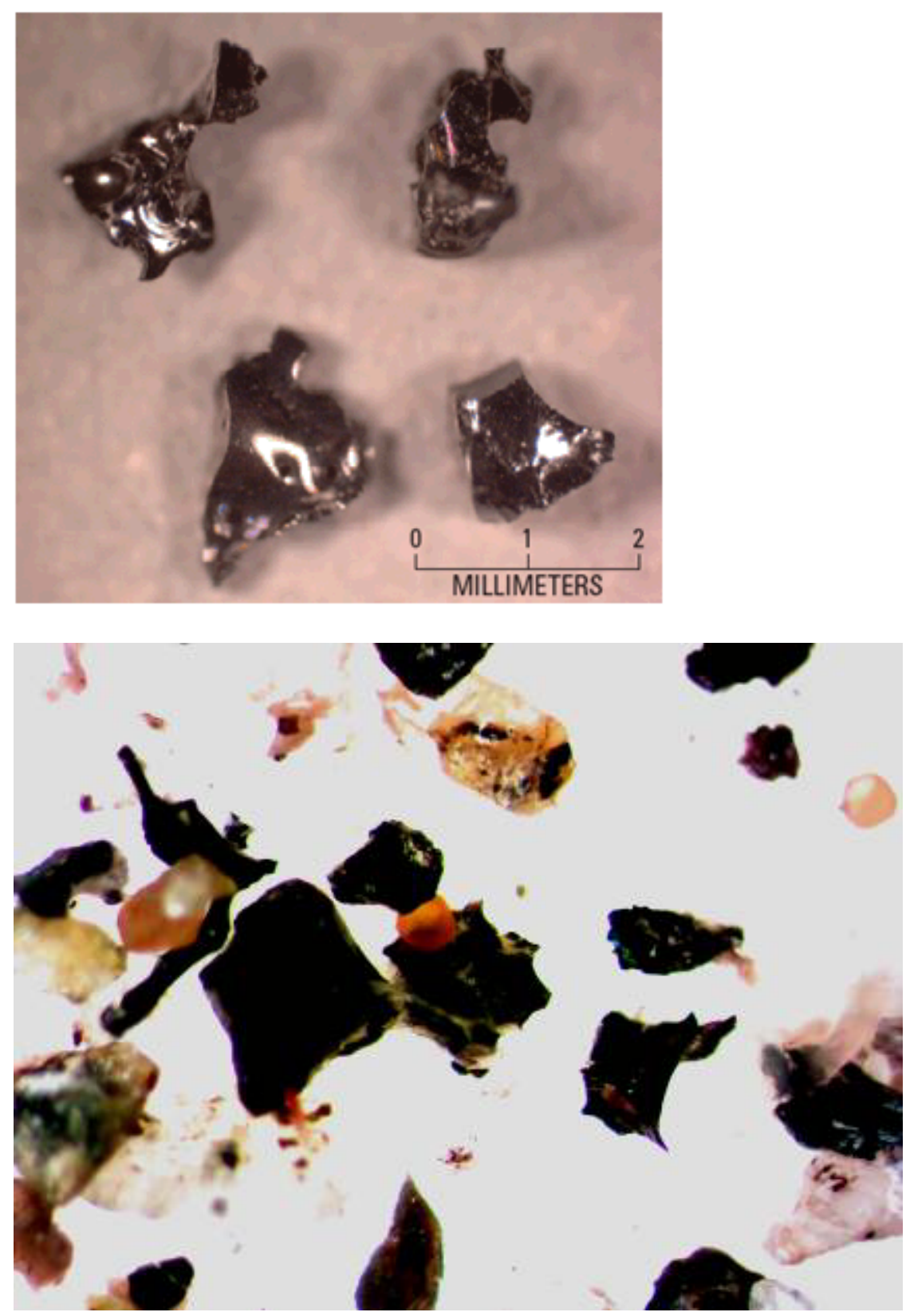

Figure 2. Photographs of a selection of slag particles (upper image) and particles observed in a Lake Roosevelt white sturgeon gut (lower image). 


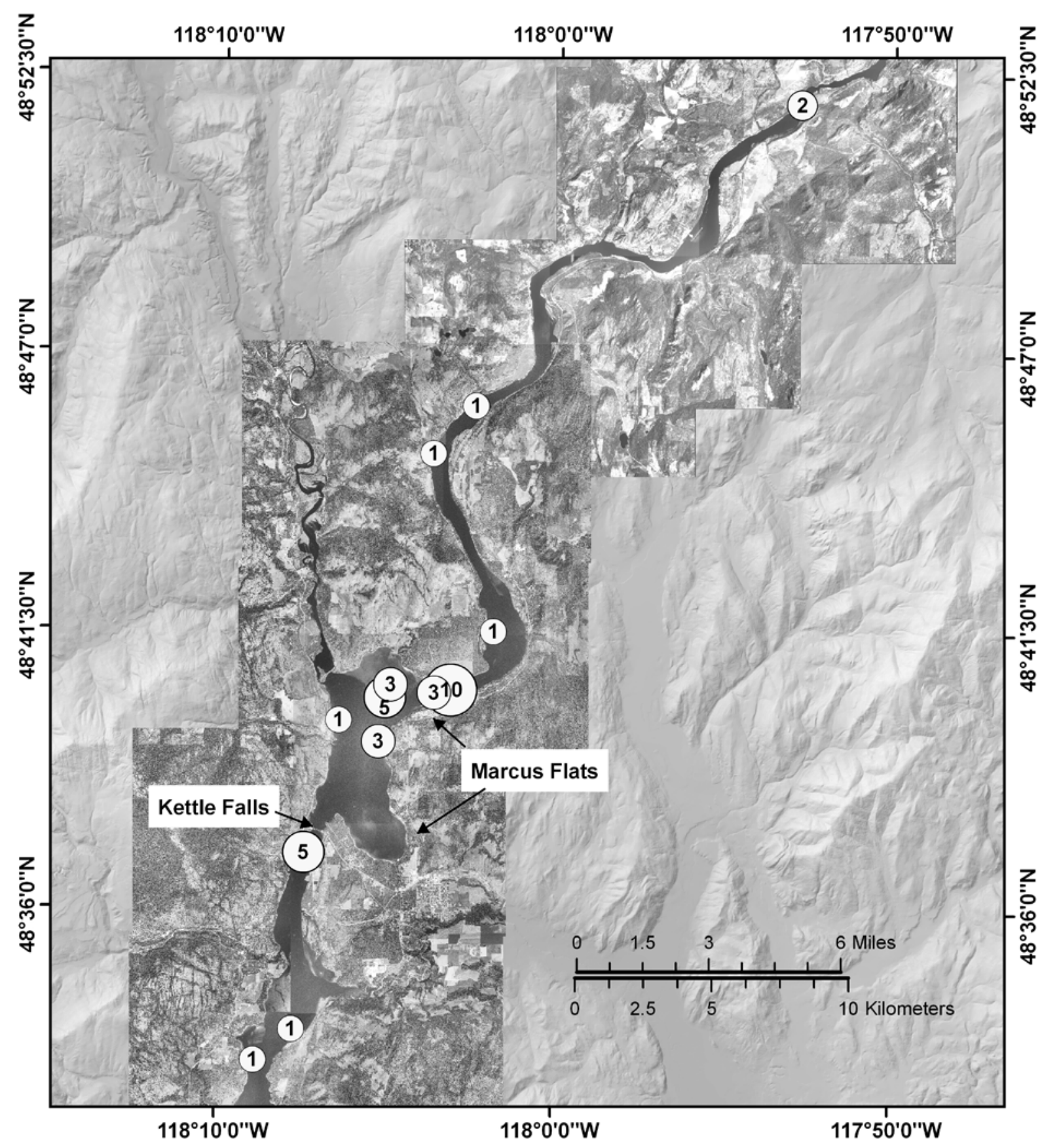

Figure 3. Map showing locations in upper Lake Roosevelt where 37 white sturgeon were captured for gut analysis. Sizes of circles (and numbers) depict the number of fish collected from each location. The lowermost location was at approximately river kilometer 1,120; the uppermost at river kilometer 1,170. 


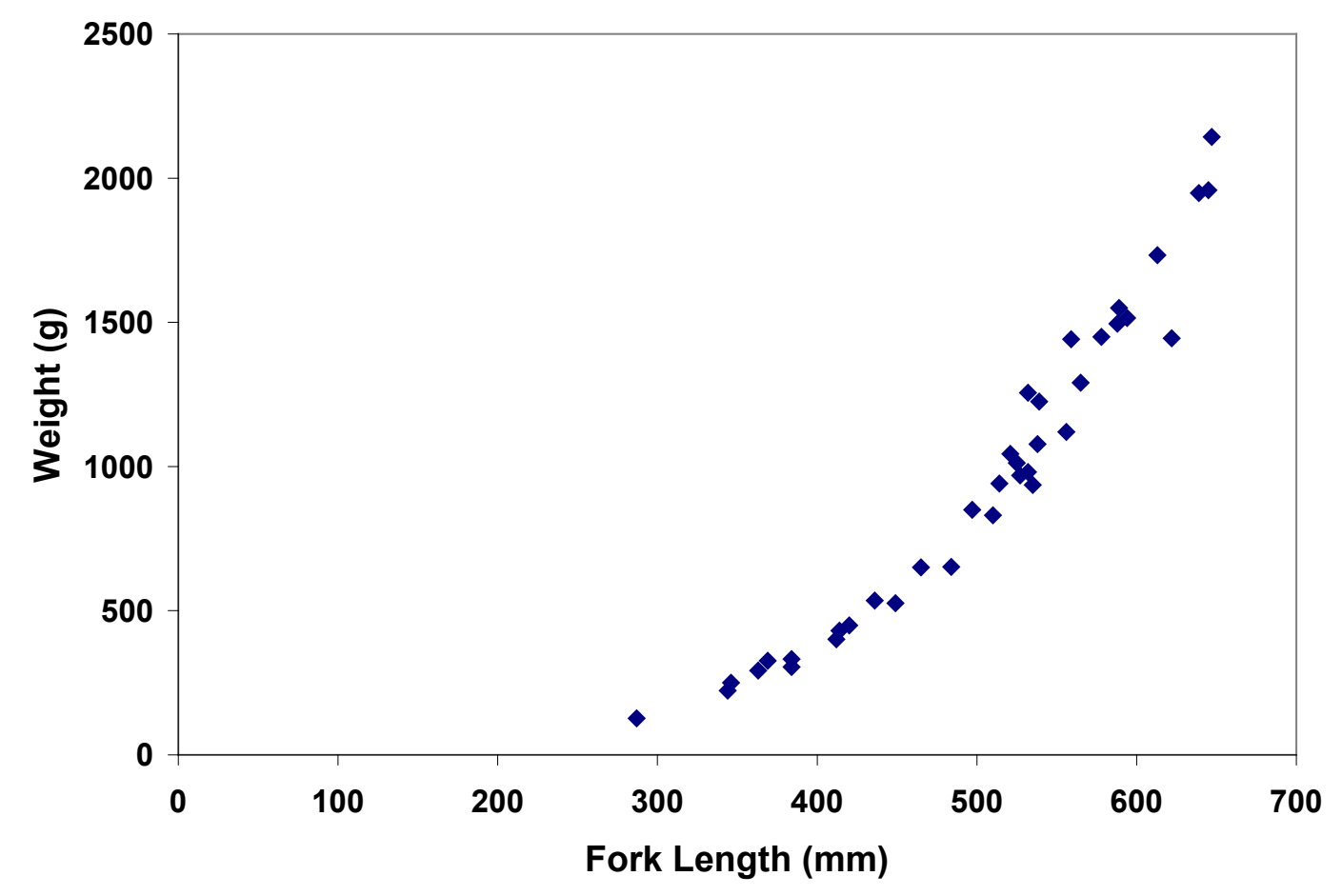

Figure 4. Plot of lengths and weights of 37 white sturgeon captured from Lake Roosevelt in October 2008.

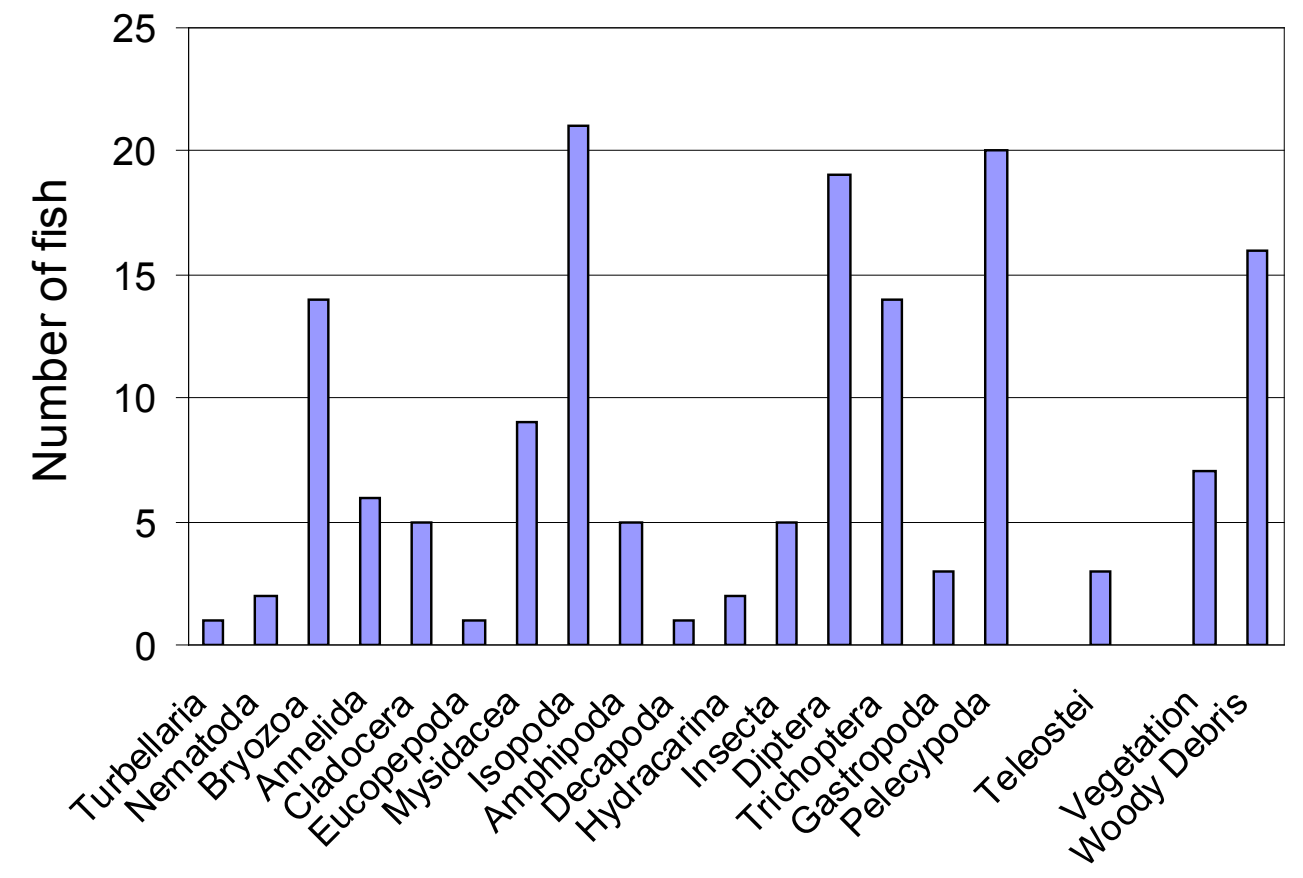

Figure 5. Graph showing categories of items observed in the gut contents of white sturgeon captured from Lake Roosevelt in October 2008. 


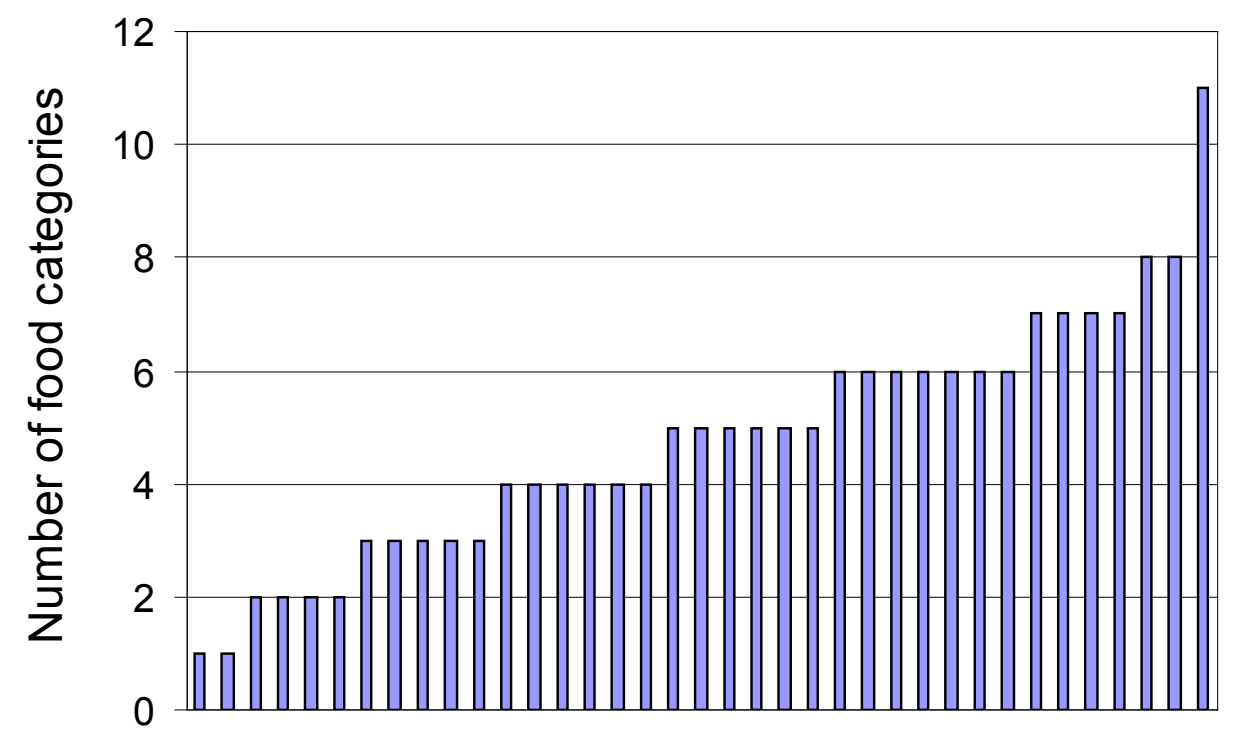

Individual fish

Figure 6. Graph showing ranked plot of the number of different categories of food items found in 37 individual white sturgeon guts from Lake Roosevelt captured in October 2008.

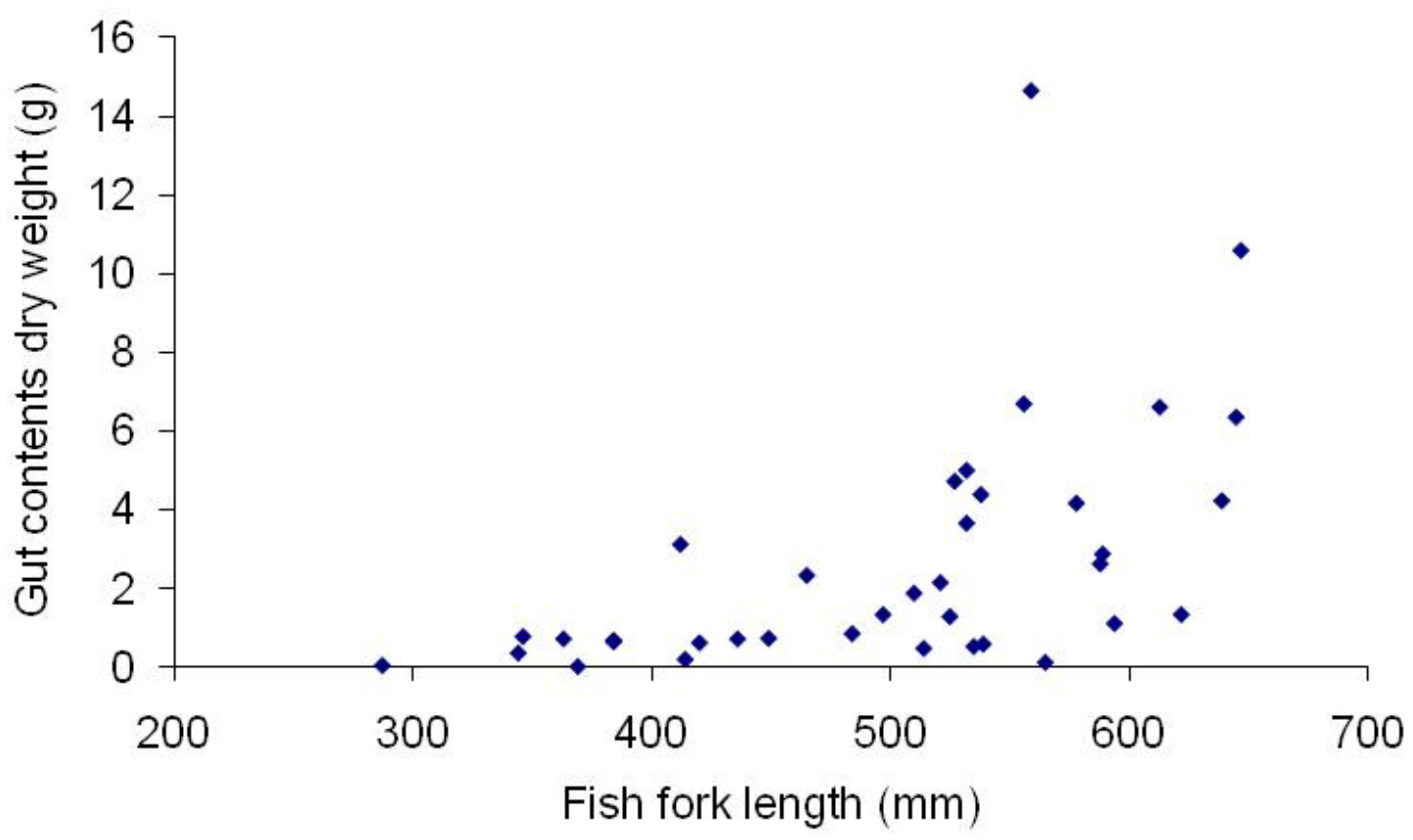

Figure 7. Graph showing dry weight of the total gut contents from individual white sturgeon from Lake Roosevelt. 


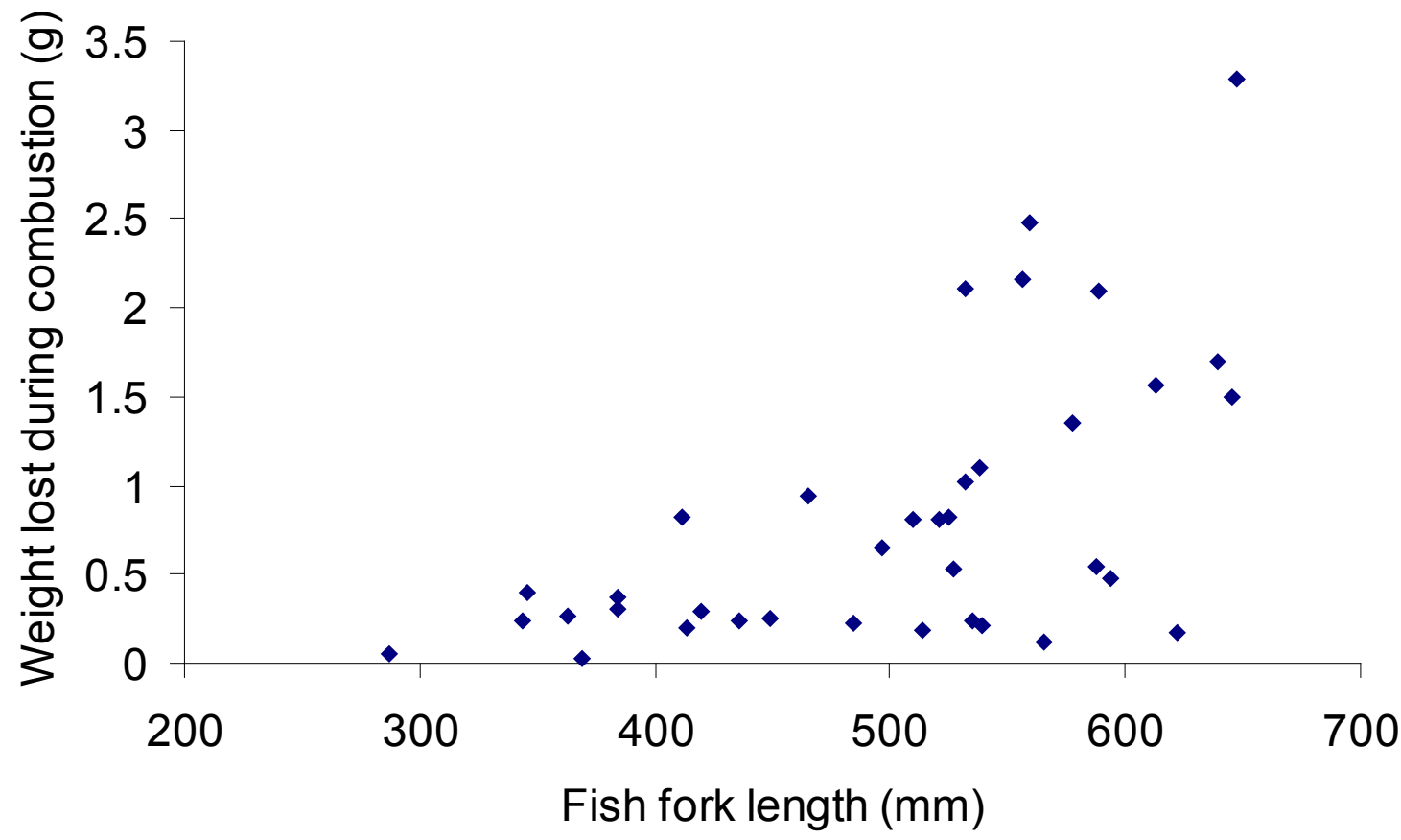

Figure 8. Graph showing weight of gut contents lost during combustion. This represents the total dry weight of potentially digestible material in the guts of white sturgeon from Lake Roosevelt.

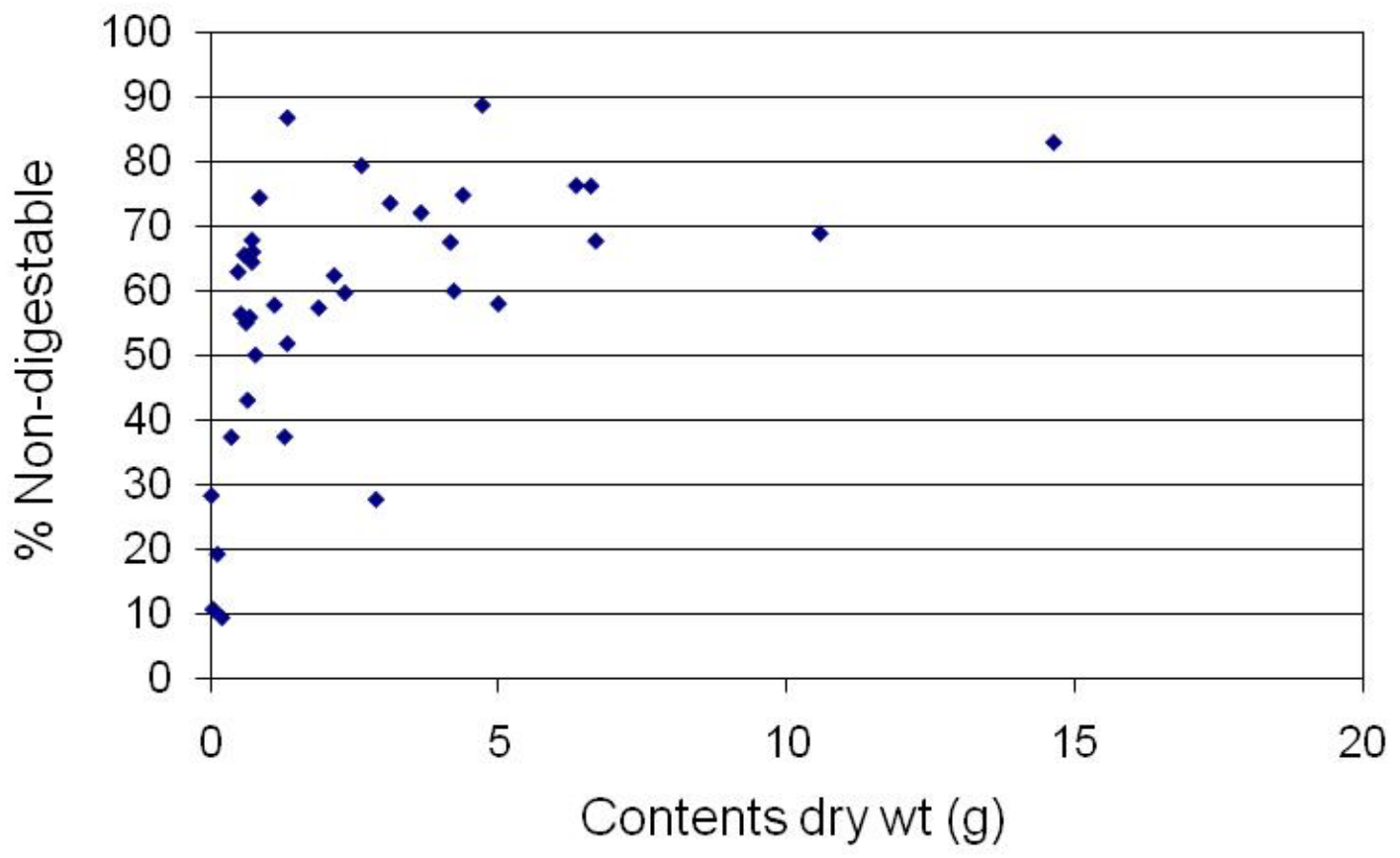

Figure 9. Graph showing non-digestable portion of the total gut contents expressed as a percentage of the total contents dry weight from individual guts. 


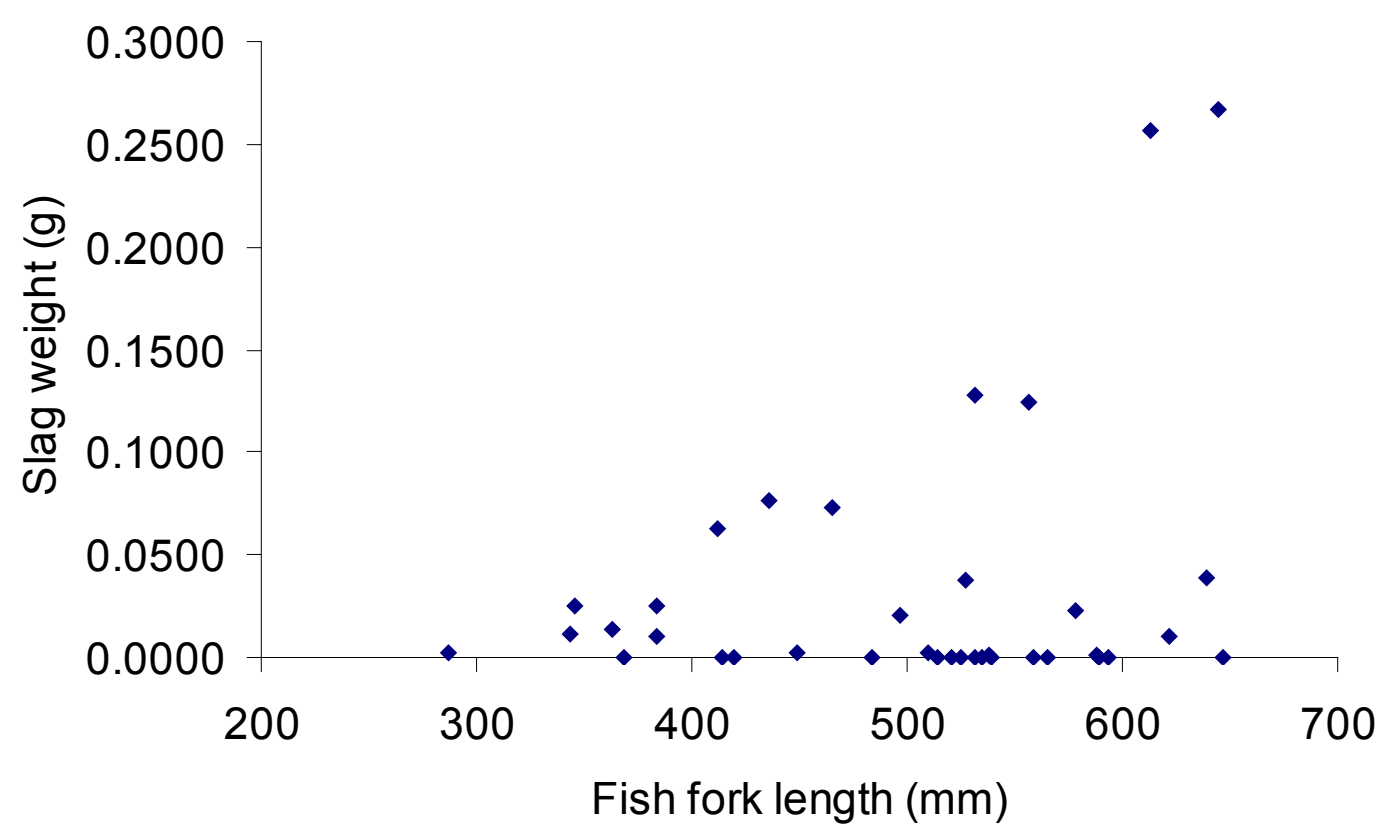

Figure 10. Graph showing weight of slag present in each gut of white sturgeon captured from Lake Roosevelt.

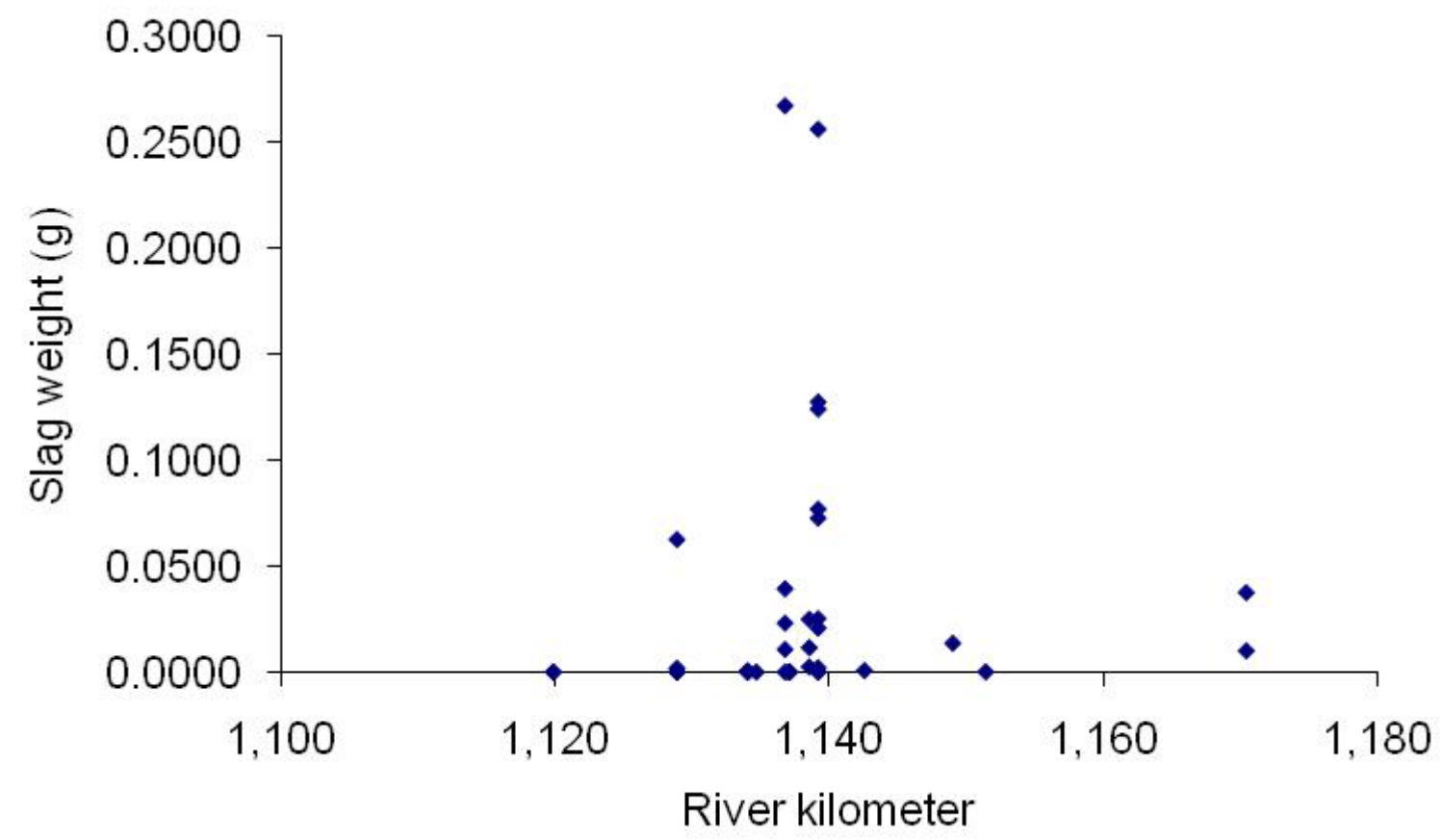

Figure 11. Graph showing the spatial distribution of the percent, by weight, of slag found in the guts of white sturgeon from Lake Roosevelt. 

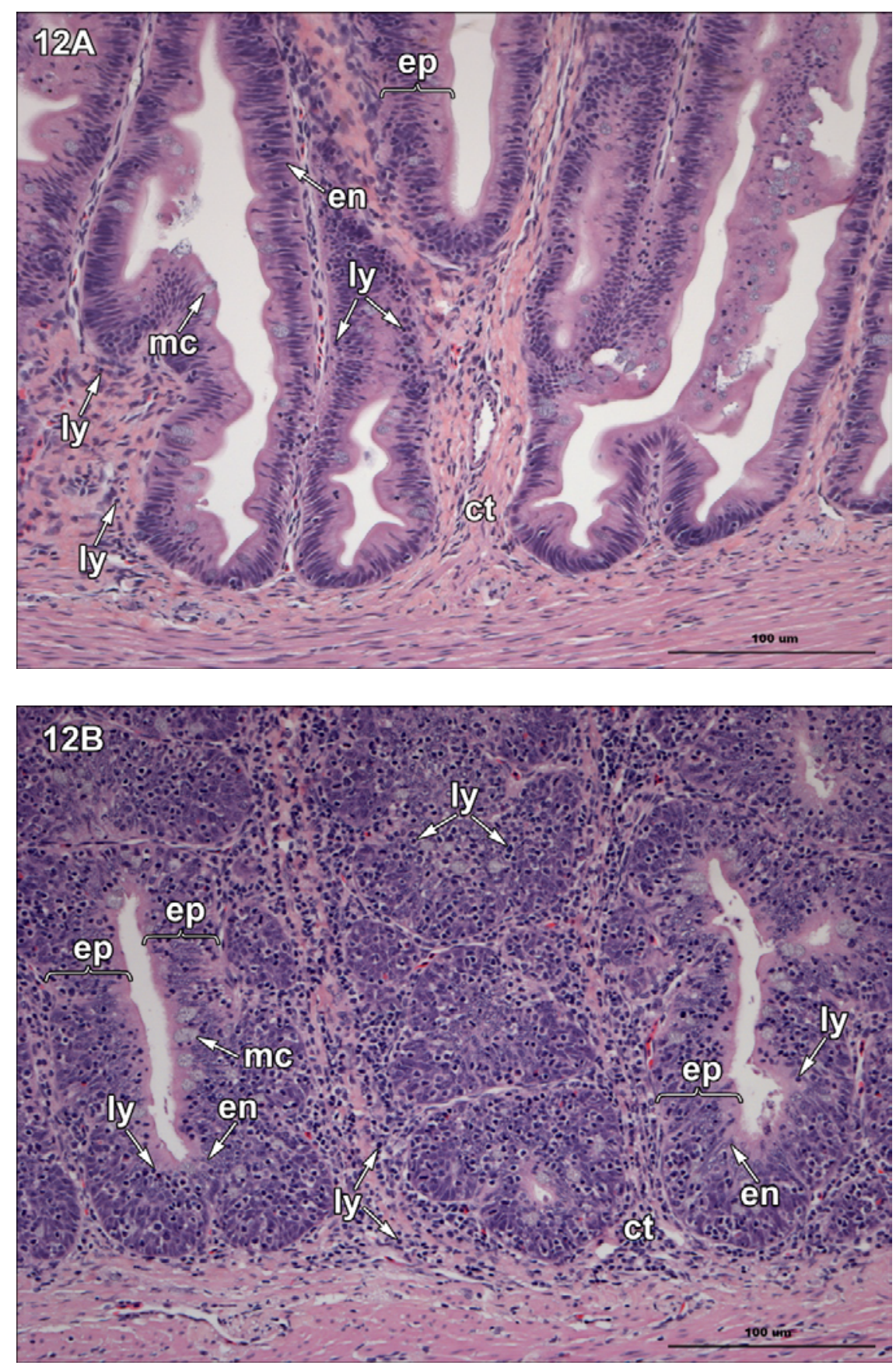

Figure 12. Photographs of histological sections of proximal (straight) intestine of juvenile white sturgeon. (A) Normal intestinal epithelium (ep) and underlying connective tissue (ct) of a CERC fish showing normal simple columnar morphology and basally aligned nuclei of the epithelial enterocytes (en). Normal mucous goblet cells (mc) are also present in the epithelium. Scattered lymphocytes (ly) are visible in the epithelium and lamina propria layer of the connective tissue. (B) The same tissues of a Lake Roosevelt fish, showing infiltration of inflammatory cells (predominantly lymphocytes, ly), in the epithelium (ep) and underlying connective tissue (ct). Thickening of the epithelium, with increased stratification of enterocytes (en) and reduction in polarity of enterocyte nuclei is visible. Mucous goblet cells (mc) are present in the epithelium. 

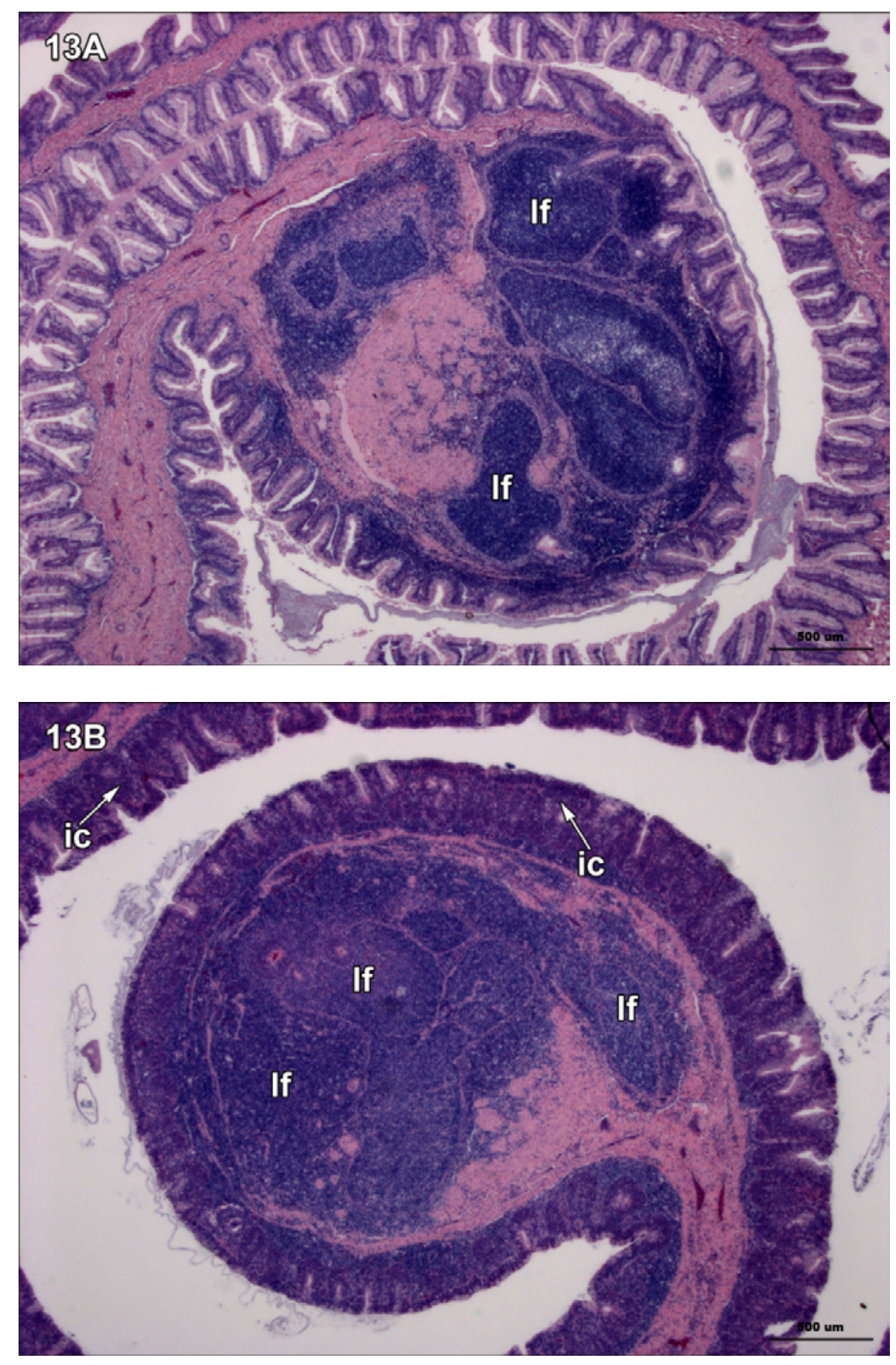

Figure 13. Photographs of histological sections of medium (spiral) intestine of juvenile white sturgeon. (A) Normal intestine of a CERC fish, with dark lymphoid follicles (If) in the central typhlosole of the spiral valve. (B) Intestine of a Lake Roosevelt shows lymphoid follicles (If) in the central typhlosole, but also increased infiltration of inflammatory cells (ic) in the intestinal mucosa (epithelium and lamina propria connective tissue layer) in comparison to the CERC fish. The inflammatory cells are predominantly lymphocytes, and are visible at low magnification as diffuse increased darkening of the intestinal mucosa in comparison to the CERC fish. 

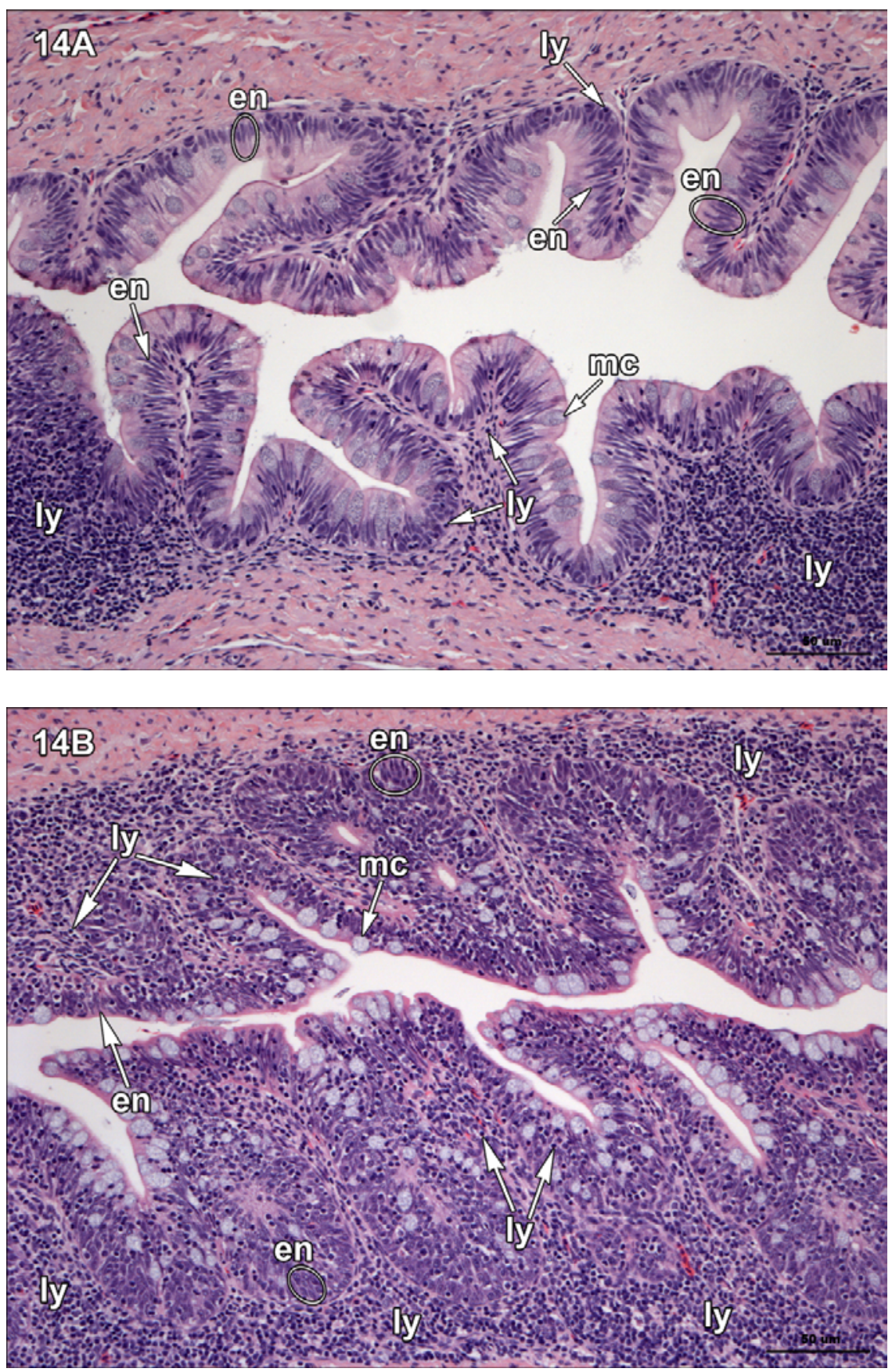

Figure 14. Photographs of histological sections of medium (spiral) intestine of juvenile white sturgeon. (A) Epithelium and underlying connective tissue of CERC fish. The epithelium shows normal morphology and nuclear orientation of enterocytes (en), and the presence of mucous goblet cells (mc). Scattered lymphocytes (ly) are present in the epithelium and both scattered and discrete aggregates of lymphocytes (ly) are visible in the connective tissue. (B) The same tissues of a Lake Roosevelt fish, showing a diffuse increase in lymphocytes (ly) in the connective tissue and epithelium, and stratified appearance of enterocytes (en) with reduction of nuclear polarity. Mucous goblet cells (mc) are also present in the epithelium. 
Table 1. Characteristics of the 37 white sturgeon captured from Lake Roosevelt in October 2008 with an assessment of gut section fullness index (SFI) and weights of contents.

$\left[\right.$ Fulton's condition factor $=$ fish weight $\left.(\text { fish fork length } / 10)^{3}\right)$. SFI was visually assessed and $0=$ empty; $1=$ some form of contents; $2=$ less than half full; $3=$ half full; 4 = greater than half full; $5=$ distended]

\begin{tabular}{|c|c|c|c|c|c|c|c|c|c|c|c|c|}
\hline $\begin{array}{l}\text { Collection } \\
\text { date }\end{array}$ & $\begin{array}{l}\text { Fish } \\
\text { fork } \\
\text { length } \\
(\mathrm{mm})\end{array}$ & $\begin{array}{l}\text { Fish } \\
\text { weight } \\
\text { (g) }\end{array}$ & $\begin{array}{l}\text { Fulton's } \\
\text { condition } \\
\text { factor }\end{array}$ & $\begin{array}{l}\text { Hatchery } \\
\text { brood } \\
\text { year }\end{array}$ & $\begin{array}{c}\text { Foregut } \\
\text { SFI }\end{array}$ & $\begin{array}{l}\text { Midgut } \\
\text { SFI }\end{array}$ & $\begin{array}{l}\text { Hindgut } \\
\text { SFI }\end{array}$ & $\begin{array}{l}\text { Gut contents } \\
\text { dry weight } \\
\text { (g) }\end{array}$ & $\begin{array}{l}\text { Weight after } \\
\text { combustion } \\
\text { (g) }\end{array}$ & $\begin{array}{l}\text { Percent } \\
\text { weight lost } \\
\text { during } \\
\text { combustion }\end{array}$ & $\begin{array}{l}\text { Weight } \\
\text { of slag } \\
\text { in gut } \\
\text { (g) }\end{array}$ & $\begin{array}{l}\text { Percent dry } \\
\text { weight } \\
\text { composed } \\
\text { of slag }\end{array}$ \\
\hline \multicolumn{13}{|c|}{ Guts fixed for histology } \\
\hline 21-Oct & 594 & 1,515 & 0.72 & 2005 & 0 & 0 & 1 & 1.12790 & 0.65187 & 42.20 & 0 & \\
\hline 21-Oct & 521 & 1,044 & 0.74 & 2006 & 4 & 3 & 0 & 2.16465 & 1.35031 & 37.62 & 0.0001 & 0.0046 \\
\hline 21-Oct & 369 & 326 & 0.65 & 2007 & 1 & 0 & 0 & 0.03729 & 0.01053 & 71.76 & 0 & \\
\hline 21-Oct & 449 & 526 & 0.58 & 2007 & 2 & 1 & 1 & 0.75058 & 0.49569 & 33.96 & 0.0018 & 0.2398 \\
\hline 21-Oct & 420 & 449 & 0.61 & 2007 & 1 & 1 & 1 & 0.63878 & 0.35163 & 44.95 & 0.0003 & 0.0470 \\
\hline 22-Oct & 484 & 652 & 0.58 & 2007 & 1 & 1 & 1 & 0.86989 & 0.64757 & 25.56 & 0 & \\
\hline 23-Oct & 344 & 223 & 0.55 & 2007 & 1 & 0 & 0 & 0.37935 & 0.14149 & 62.70 & 0.0115 & 3.0315 \\
\hline 23-Oct & 346 & 250 & 0.60 & 2007 & 3 & 2 & 4 & 0.79925 & 0.39999 & 49.95 & 0.0249 & 3.1154 \\
\hline 23-Oct & 510 & 831 & 0.63 & 2006 & 4 & 4 & 4 & 1.89470 & 1.08669 & 42.65 & 0.0024 & 0.1267 \\
\hline 23-Oct & 535 & 936 & 0.61 & 2006 & 1 & 0 & 1 & 0.54647 & 0.30823 & 43.60 & 0.0001 & 0.0183 \\
\hline 24-Oct & 532 & 1,256 & 0.83 & 2005 & 5 & 5 & 5 & 5.00827 & 2.90512 & 41.99 & 0 & \\
\hline 24-Oct & 589 & 1,550 & 0.76 & 2005 & 5 & 4 & 5 & 2.88902 & 0.79870 & 72.35 & 0 & \\
\hline 24-Oct & 639 & 1,948 & 0.75 & 2005 & 3 & 3 & 3 & 4.23922 & 2.54230 & 40.03 & 0.0393 & 0.9271 \\
\hline 24-Oct & 539 & 1,225 & 0.78 & 2005 & 0 & 0 & 2 & 0.60608 & 0.39733 & 34.44 & 0 & \\
\hline 24-Oct & 525 & 1,012 & 0.70 & 2006 & 4 & 1 & 4 & 1.30447 & 0.48735 & 62.64 & 0 & \\
\hline 24-Oct & 514 & 941 & 0.69 & 2005 & 0 & 0 & 2 & 0.49719 & 0.31287 & 37.07 & 0 & \\
\hline 24-Oct & 384 & 305 & 0.54 & 2007 & 1 & 1 & 4 & 0.66236 & 0.28507 & 56.96 & 0.0107 & 1.6154 \\
\hline 24-Oct & 588 & 1,495 & 0.74 & 2006 & 0 & 0 & 3 & 2.63784 & 2.09545 & 20.56 & 0.0006 & 0.0227 \\
\hline 24-Oct & 565 & 1,291 & 0.72 & 2006 & 1 & 0 & 0 & 0.14177 & 0.02716 & 80.84 & 0.0001 & 0.0705 \\
\hline 24-Oct & 559 & 1,441 & 0.82 & 2005 & 5 & 4 & 4 & 14.62986 & 12.14485 & 16.99 & 0 & 0 \\
\hline 24-Oct & 647 & 2,143 & 0.79 & 2006 & 4 & 2 & 4 & 10.58272 & 7.29463 & 31.07 & 0.0001 & 0.0009 \\
\hline
\end{tabular}


Table 1. Characteristics of the 37 white sturgeon captured from Lake Roosevelt in October 2008 with an assessment of gut section fullness index (SFI) and weights of contents.-Continued.

[Fulton's condition factor $=$ fish weight $\left.(\text { fish fork length } / 10)^{3}\right)$. SFI was visually assessed and $0=$ empty; $1=$ some form of contents; $2=$ less than half full; $3=$ half full; $4=$ greater than half full; $5=$ distended]

\begin{tabular}{|c|c|c|c|c|c|c|c|c|c|c|c|c|}
\hline $\begin{array}{l}\text { Collection } \\
\text { date }\end{array}$ & $\begin{array}{l}\text { Fish } \\
\text { fork } \\
\text { length } \\
(\mathrm{mm})\end{array}$ & $\begin{array}{l}\text { Fish } \\
\text { weight } \\
\text { (g) }\end{array}$ & $\begin{array}{l}\text { Fulton's } \\
\text { condition } \\
\text { factor }\end{array}$ & $\begin{array}{l}\text { Hatchery } \\
\text { brood } \\
\text { year }\end{array}$ & $\begin{array}{c}\text { Foregut } \\
\text { SFI }\end{array}$ & $\begin{array}{c}\text { Midgut } \\
\text { SFI }\end{array}$ & $\begin{array}{l}\text { Hindgut } \\
\text { SFI }\end{array}$ & $\begin{array}{c}\text { Gut } \\
\text { contents } \\
\text { dry weight } \\
\text { (g) }\end{array}$ & $\begin{array}{l}\text { Weight after } \\
\text { combustion } \\
\text { (g) }\end{array}$ & $\begin{array}{l}\text { Percent } \\
\text { weight lost } \\
\text { during } \\
\text { combustion }\end{array}$ & $\begin{array}{l}\text { Weight } \\
\text { of slag } \\
\text { in gut } \\
\text { (g) }\end{array}$ & $\begin{array}{l}\text { Percent dry } \\
\text { weight } \\
\text { composed } \\
\text { of slag }\end{array}$ \\
\hline \multicolumn{13}{|c|}{ Guts frozen in the field } \\
\hline 21-Oct & 412 & 401 & 0.57 & 2007 & 4 & 4 & 4 & 3.13469 & 2.30750 & 26.39 & 0.0625 & 1.9938 \\
\hline 24-Oct & 622 & 1,445 & 0.60 & 2004 & 2 & 2 & 0 & 1.35444 & 1.17638 & 13.15 & 0.0100 & 0.7383 \\
\hline 24-Oct & 532 & 981 & 0.65 & 2006 & 1 & 0 & 5 & 3.66657 & 2.64395 & 27.89 & 0.1274 & 3.4746 \\
\hline 24-Oct & 384 & 332 & 0.59 & 2007 & 5 & 0 & 4 & 0.69978 & 0.39116 & 44.10 & 0.0252 & 3.6011 \\
\hline 24-Oct & 645 & 1,958 & 0.73 & 2005 & 0 & 0 & 4 & 6.35780 & 4.85373 & 23.66 & 0.2672 & 4.2027 \\
\hline 24-Oct & 578 & 1,450 & 0.75 & 2005 & 3 & 1 & 4 & 4.17809 & 2.82169 & 32.46 & 0.0231 & 0.5529 \\
\hline 24-Oct & 527 & 969 & 0.66 & 2004 & 2 & 4 & 4 & 4.73077 & 4.20082 & 11.20 & 0.0375 & 0.7927 \\
\hline 24-Oct & 538 & 1,078 & 0.69 & 2005 & 5 & 0 & 5 & 4.39581 & 3.29072 & 25.14 & 0.0007 & 0.0159 \\
\hline 24-Oct & 556 & 1,120 & 0.65 & 2005 & 4 & 3 & 5 & 6.69605 & 4.53660 & 32.25 & 0.1241 & 1.8533 \\
\hline 24-Oct & 613 & 1,733 & 0.75 & 2005 & 2 & 1 & 5 & 6.61251 & 5.04228 & 23.75 & 0.2561 & 3.8730 \\
\hline 24-Oct & 414 & 431 & 0.61 & 2006 & 1 & 0 & 2 & 0.21683 & 0.02019 & 90.69 & 0.0001 & 0.0461 \\
\hline 24-Oct & 465 & 650 & 0.65 & 2006 & 0 & 0 & 4 & 2.34880 & 1.40166 & 40.32 & 0.0726 & 3.0909 \\
\hline 24-Oct & 436 & 535 & 0.65 & 2006 & 0 & 0 & 1 & 0.73788 & 0.50062 & 32.15 & 0.0769 & 10.4218 \\
\hline 24-Oct & 497 & 850 & 0.69 & 2006 & 1 & 0 & 2 & 1.35279 & 0.70108 & 48.18 & 0.0207 & 1.5302 \\
\hline 24-Oct & 287 & 127 & 0.54 & 2007 & 1 & 1 & 0 & 0.06363 & 0.00674 & 89.41 & 0.0021 & 3.3001 \\
\hline 24-Oct & 363 & 292 & 0.61 & 2007 & 4 & 0 & 3 & 0.73973 & 0.47681 & 35.54 & 0.0136 & 1.8385 \\
\hline
\end{tabular}


Table 2. Lengths and weights, weight of slag in gut, and intestinal histopathology scores for 14 white sturgeon captured from Lake Roosevelt in October 2008, and comparison with 7 white sturgeon obtained from the CERC.

[CERC, Columbia Environmental Research Center; NA, not applicable; mm, millimeter; g, gram]

\begin{tabular}{lcccc}
\hline \multicolumn{1}{c}{ Fish No. } & $\begin{array}{c}\text { Fish fork length } \\
(\mathbf{m m})\end{array}$ & $\begin{array}{c}\text { Fish weight } \\
(\mathbf{g})\end{array}$ & $\begin{array}{c}\text { Weight of } \\
\text { slag in gut } \\
(\mathbf{g})\end{array}$ & $\begin{array}{c}\text { Intestinal } \\
\text { Histopathology } \\
\text { Score }\end{array}$ \\
\hline CERC Fish & & & & \\
\hline C 1 & 615 & 1,520 & NA & 26.5 \\
C 2 & 618 & 1,435 & NA & 27.0 \\
C 3 & 648 & 1,500 & NA & 25.3 \\
C 4 & 609 & 1,520 & NA & 31.0 \\
C 8 & 546 & 875 & NA & 28.0 \\
C 9 & 576 & 1,295 & NA & 25.3 \\
C 10 & 591 & 1,245 & NA & 27.3 \\
\hline Lake Roosevelt Fish & & & \\
\hline LR 1 & 594 & 1,515 & 0 & 72.1 \\
LR 2 & 484 & 652 & 0 & 62.4 \\
LR 3 & 344 & 223 & 0.0115 & 68.0 \\
LR 4 & 346 & 250 & 0.0249 & 57.6 \\
LR 6 & 535 & 936 & 0.0001 & 79.5 \\
LR 1 & 1,012 & 0 & 81.0 \\
LR 13 & 325 & 1,291 & 0.0107 & 49.5 \\
LR 15 & 384 & 1,441 & 0.0001 & 85.5 \\
LR 16 & 565 & 1,044 & 0 & 77.0 \\
LR 21A & 559 & 326 & 0.0001 & 79.2 \\
LR 22A & 521 & 526 & 0 & 69.3 \\
LR 23 & 369 & 401 & 0.0018 & 57.3 \\
LR 24 & 449 & 449 & 0.0625 & 63.0 \\
LR 25 & 412 & 0.0003 & 66.8 \\
\hline
\end{tabular}

${ }^{1}$ Histopathology score was calculated by adding distribution (scale $0-3$ ) and severity (scale $0-4$ ) scores for five histopathological changes in three areas of the intestine: pyloric caecum, straight intestine, and spiral intestine. The histopathological changes that were scored included lymphocytic infiltrate in lamina propria, lymphocytic infiltrate in epithelium, stratification of enterocytes, reduction in enterocyte polarity, and apoptosis of cells in the epithelium. 
Publishing support provided by the U.S. Geological Survey

Publishing Network, Tacoma Publishing Service Center

For more information concerning the research in this report, contact the Director, Western Fisheries Research Center U.S. Geological Survey, 6505 NE 65th Street Seattle, Washington 98115

http://wfrc.usgs.gov/ 
